N evada

Environmental

Restoration

Project

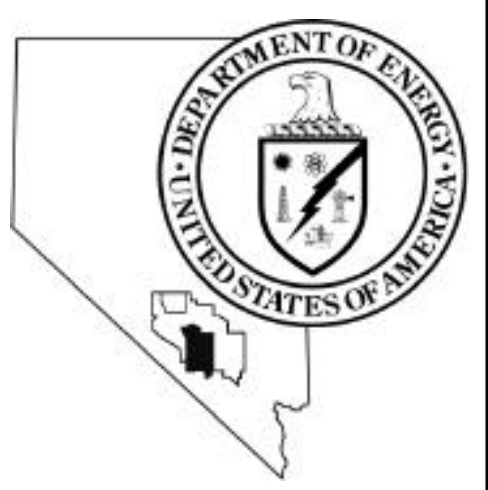

Corrective Action Investigation Plan for Corrective Action Unit 252:

Area 25 Engine Test Stand 1

Decontam ination Pad,

$N$ evada Test $S$ ite, $N$ evada

Controlled Copy N $0 .:$

Revision N 0.: 0

August 1999

Approved for public release; further dissemination unlimited.

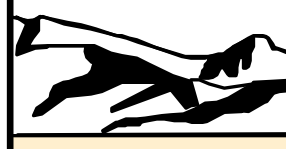

Environm ental Restoration

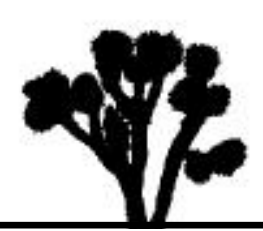

Division 
Available to the public from -

U.S. Department of Commerce

National Technical Information Service

5285 Port Royal Road

Springfield, VA 22161

(703) 487-4650

Available electronically at http://www.doe.gov/bridge. Available to U.S. Department of Energy and its contractors in paper from -

U.S. Department of Energy

Office of Scientific and Technical Information

P.O. Box 62

Oak Ridge, TN 37831-0062

(423) 576-8401

Reference herein to any specific commercial product, process, or service by trade name, trademark, manufacturer, or otherwise, does not necessarily constitute or imply its endorsement, recommendation, or favoring by the United States Government or any agency thereof or its contractors or subcontractors. 


\title{
CORRECTIVE ACTION INVESTIGATION PLAN FOR CORRECTIVE ACTION UNIT 252: AREA 25 ENGINE TEST STAND 1 DECONTAMINATION PAD, NEVADA TEST SITE, NEVADA
}

\author{
DOE Nevada Operations Office \\ Las Vegas, Nevada
}

Controlled Copy No.:

Revision No.: 0

\section{August 1999}

Approved for public release; further dissemination unlimited. 


\title{
CORRECTIVE ACTION INVESTIGATION PLAN \\ FOR CORRECTIVE ACTION UNIT 252: \\ AREA 25 ENGINE TEST STAND 1 \\ DECONTAMINATION PAD, NEVADA TEST SITE, NEVADA
}

\author{
Approved by:_ Signature Approved Date: 8/20/99 \\ Janet Appenzeller-Wing, Project Manager \\ Industrial Sites Project
}

Approved by: $\quad$ Signature Approved _ Date: $\quad$ 8/20/99

Runore C. Wycoff, Division Director

Environmental Restoration Division 


\section{Table of Contents}

List of Figures $\ldots \ldots \ldots \ldots \ldots \ldots \ldots \ldots \ldots \ldots \ldots \ldots \ldots \ldots \ldots \ldots \ldots \ldots \ldots \ldots$

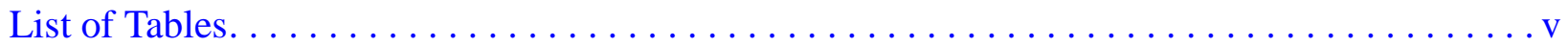

List of Acronyms and Abbreviations $\ldots \ldots \ldots \ldots \ldots \ldots \ldots \ldots \ldots \ldots \ldots \ldots \ldots \ldots \ldots \ldots$

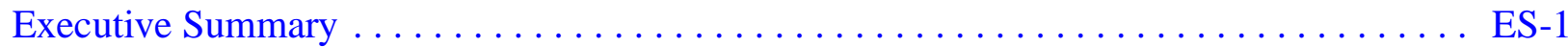

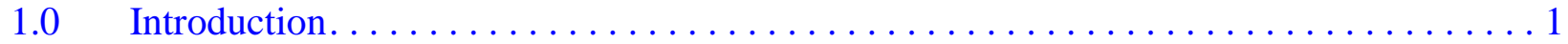

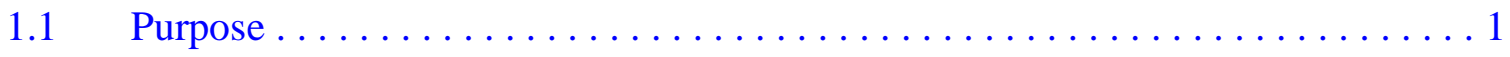

$1.2 \quad$ Scope. ................................... 4

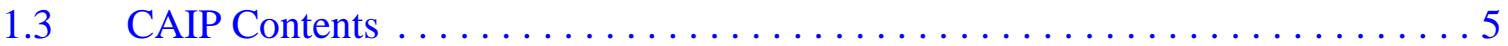

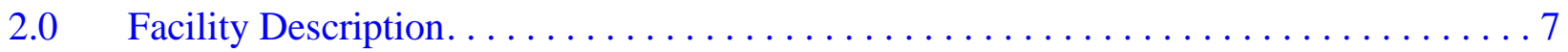

$2.1 \quad$ Physical Setting. . . . . . . . . . . . . . . . . . .

2.2 Operational History. . . . . . . . . . . . . . . . . . . . . 9

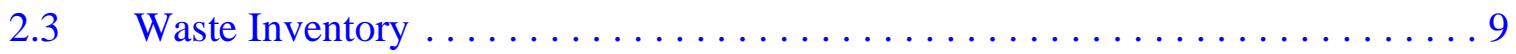

$2.4 \quad$ Release Information . . . . . . . . . . . . . . . . . . . . . . . . 10

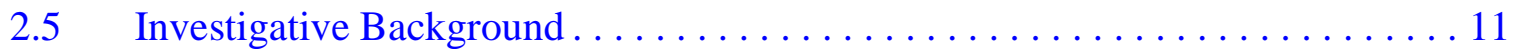

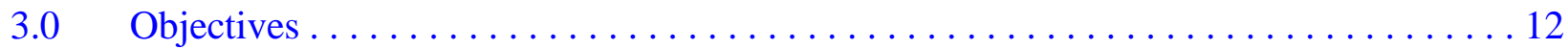

$3.1 \quad$ Conceptual Site Model . . . . . . . . . . . . . . . . . . . . . . . . . . . . . 12

3.2 Contaminants of Potential Concern $\ldots \ldots \ldots \ldots \ldots \ldots \ldots \ldots \ldots \ldots \ldots \ldots \ldots \ldots \ldots$

3.3 Preliminary Action Levels . . . . . . . . . . . . . . . . . . 13

3.3.1 Field-Screening Levels. . . . . . . . . . . . . . . . 13

3.3.2 Chemical Preliminary Action Levels . . . . . . . . . . . . . . . . . . . 14

3.3.3 Radiological Preliminary Action Levels . . . . . . . . . . . . . 14

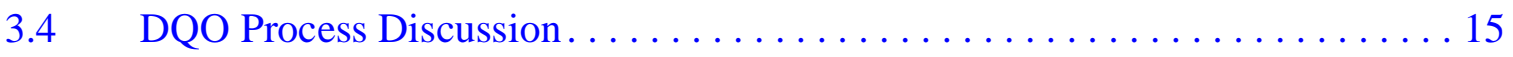

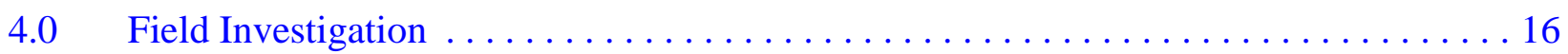

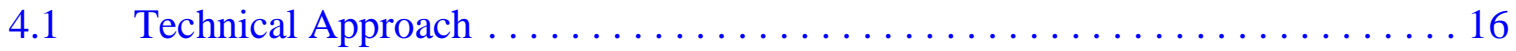

4.2 Field Activities . . . . . . . . . . . . . . . . . . 18

4.2.1 Test Pit Excavation and Soil Sampling . . . . . . . . . . . 18

4.2.2 Video/Geophysical Survey. . . . . . . . . . . . . . . . . 19

4.2.3 Field Screening and Field Surveys . . . . . . . . . . . . . . . . . 19

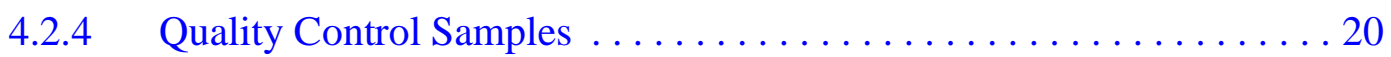




\section{Table of Contents (Continued)}

$5.0 \quad$ Waste Management. . . . . . . . . . . . . . . . . . . . . . 21

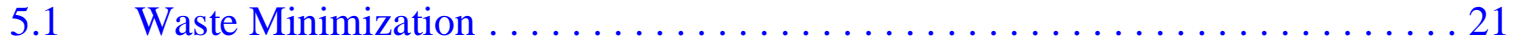

5.2 Potential Waste Streams . . . . . . . . . . . . . . . . . . 22

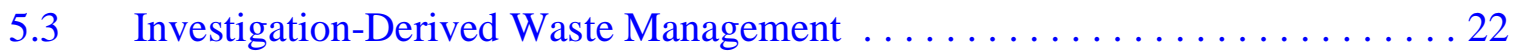

$5.3 .1 \quad$ Sanitary Waste . . . . . . . . . . . . . . . . . . . . . . . . . . 23

5.3.2 Low-Level Radioactive Waste . . . . . . . . . . . . . . . . . . 23

5.3 .3 Hazardous Waste . . . . . . . . . . . . . . . . 23

5.3 .4 Mixed Wastes............................ 25

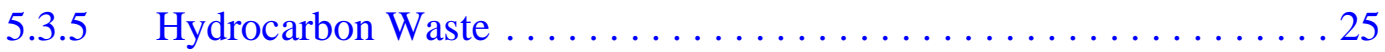

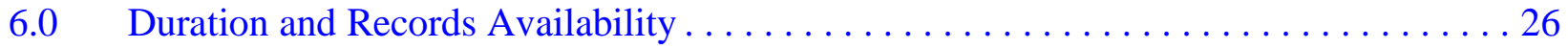

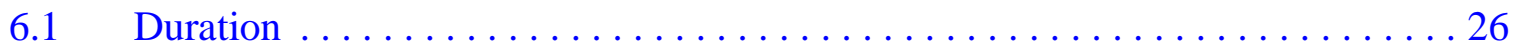

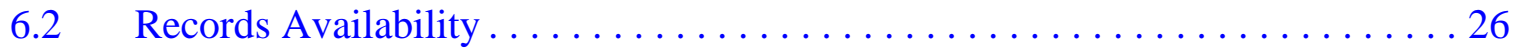

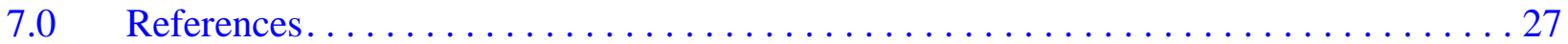

\section{Appendix A - Data Quality Objectives Worksheets}

A.1.0 Introduction. . . . . . . . . . .

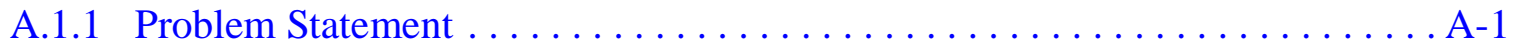

A.1.2 DQO Kickoff Meeting . . . . . . . . . . . . . . . . . A-1

A.2.0 Conceptual Model. . . . . . . . . . . . . . . . . . . . . . . . . A-4

A.3.0 Potential Contaminants. . . . . . . . . . . . . . . . . . . . . A-7

A.3.1 Decisions. . . . . . . . . . . . . . . . . . . . . . . . . A-9

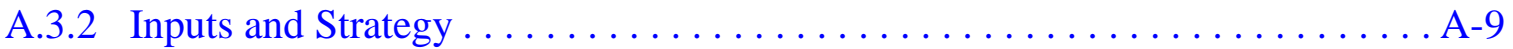

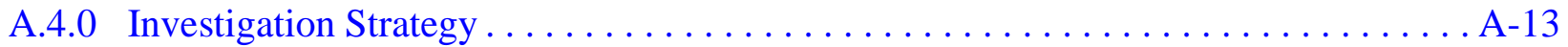

A.5.0 Decision Rules . . . . . . . . . . . . . . . . . . . . . . . . . . . . A-15

A.6.0 Decision Error . . . . . . . . . . . . . . . . . . . . . . . . A-17

A.7.0 References.................................... A-18

\section{Appendix B - Project Organization}

B.1.0 Project Organization $\ldots \ldots \ldots \ldots \ldots \ldots \ldots \ldots \ldots \ldots \ldots \ldots \ldots \ldots \ldots \ldots \ldots \ldots \ldots \ldots \ldots$ 


\section{Table of Contents (Continued)}

Appendix C - Laboratory Chemical, Toxicity Characteristic Leaching Procedure, and Radiochemistry Analytical Requirements for Industrial Sites

C.1.0 References.............................................

Appendix D - NDEP Comment Responses 


\section{List of Figures}

Number

1-1 Nevada Test Site and CAU 252 Engine Test Stand -1 Decontamination Pad Location Map, Nevada. . . . . . . . . . . . . . . . . . . . . . . . . . . . . . . 2

1-2 CAU 252, Area 25, Engine Test Stand-1 Decontamination Pad Location, Nevada Test Site. . . . . . . . . . . . . . . . . . . . . . . . . . . . . . . 3

2-1 CAU 252, Area 25 Engine Test Stand-1 Decontamination Pad Layout. . . . . . . . 8

A.1-1 CAU 252, Area 25 Engine Test Stand - 1 Decontamination Pad and Planned Test Pit Locations............................... A-2 


\section{List of Tables}

Number

A.1-1 DQO Kickoff Meeting Participants April 28, $1999 \ldots \ldots \ldots \ldots \ldots \ldots \ldots \ldots$. . . . . .

A.2-1 CAU 252 Conceptual Model Element Descriptions . . . . . . . . . . . . . A-5

A.3-1 CAU 252 ETS-1 Decontamination Pad Contaminants of Potential Concern ... . . A-8

A.3-2 CAU 252 Decisions, Inputs, and General Strategies. . . . . . . . . . . . . A-10

A.5-1 CAU 252 Site-Specific Decision Points and Rules.................. A-16

C.1-1 Laboratory Chemical, Toxicity Characteristic Leaching Procedure, and Radiochemistry Analytical Requirements for Industrial Sites . . . . . . . . . . . C-1 


\section{List of Acronyms and Abbreviations}

\begin{tabular}{|c|c|}
\hline ALARA & As low as reasonably achievable \\
\hline bgs & Below ground surface \\
\hline CADD & Corrective Action Decision Document \\
\hline CAIP & Corrective Action Investigation Plan \\
\hline CAS & Corrective Action Site(s) \\
\hline CAU & Corrective Action Unit(s) \\
\hline CFR & Code of Federal Regulations \\
\hline $\mathrm{COPC}$ & Contaminant(s) of potential concern \\
\hline $\mathrm{CR}$ & Closure Report \\
\hline DOE & U.S. Department of Energy \\
\hline DOE/NV & U.S. Department of Energy, Nevada Operations Office \\
\hline DOT & U.S. Department of Transportation \\
\hline DQO & Data Quality Objective(s) \\
\hline EPA & U.S. Environmental Protection Agency \\
\hline ETS-1 & Engine Test Stand-1 \\
\hline FFACO & Federal Facility Agreement and Consent Order \\
\hline FSL & Field-screening level(s) \\
\hline $\mathrm{ft}$ & Foot (feet) \\
\hline HWAA & Hazardous Waste Accumulation Area \\
\hline IDW & Investigation-derived waste \\
\hline in. & $\operatorname{Inch}(\mathrm{es})$ \\
\hline LLW & Low-level radioactive waste \\
\hline $\mathrm{mi}$ & Mile(s) \\
\hline MS/MSD & Matrix spike/matrix spike duplicate \\
\hline NAC & Nevada Administrative Code \\
\hline $\mathrm{NaI}$ & Sodium iodide \\
\hline
\end{tabular}




\section{List of Acronyms and Abbreviations (Continued)}

NDEP Nevada Division of Environmental Protection

NEPA National Environmental Policy Act

NRDS Nuclear Rocket Development Station

NTS Nevada Test Site

NTSWAC Nevada Test Site Waste Acceptance Criteria

PAL Preliminary action level(s)

PCB Polychlorinated biphenyl(s)

PID Photoionization detector

PPE Personal protective equipment

ppm Part(s) per million

PRG Preliminary Remediation Goal(s)

QAPP Quality Assurance Project Plan

QA/QC Quality assurance/quality control

QC Quality control

RCRA Resource Conservation and Recovery Act

SVOC Semivolatile organic compound(s)

TCLP Toxicity characteristic leaching procedure

TID Tamper-indicating device(s)

TPH Total petroleum hydrocarbons

VOC Volatile organic compound(s) 


\section{Executive Summary}

This Corrective Action Investigation Plan contains the environmental sample collection objectives and the criteria for conducting site investigation activities for Corrective Action Unit 252, Corrective Action Site 25-07-04, Area 25 Engine Test Stand-1 Decontamination Pad, at the Nevada Test Site. The Corrective Action Investigation Plan has been developed in accordance with the Federal Facility Agreement and Consent Order agreed to by the U.S. Department of Energy, Nevada Operations Office; the State of Nevada Division of Environmental Protection; and the U.S. Department of Defense.

The Engine Test Stand-1 Decontamination Pad is located in Area 25 at the intersection of Road H and Road $\mathrm{K}$ and was designed for use as a mobile radiation checkpoint and for vehicle decontamination. The corrective action site consists of a concrete decontamination pad with a drain, a gravel-filled sump, two concrete trailer pads, and utility boxes. Contaminants of potential concern for the site include radionuclides, total volatile organic compounds, total semivolatile compounds, total petroleum hydrocarbons-as diesel range organics, Resource Conservation and Recovery Act metals, total pesticides, and polychlorinated biphenyls. Additional samples may also be collected at the discretion of the Site Supervisor. The formulation of a conceptual site model was used as an aid for the development of Data Quality Objectives for the site. The technical approach for investigating the site was discussed during the Data Quality Objective meeting held on April 28, 1999. The investigative strategy includes the following activities:

- Conduct a utility survey prior to excavation activities.

- Determine radiological field-screening levels using an Electra alpha/beta scintillator, a sodium iodide detector, or intrinsic germanium detector (or equivalent) by taking 20 background sample readings and calculating the mean plus two standard deviations.

- Remove the gravel-fill from test pit locations in the sump with a backhoe prior to sampling soil in the sump.

- Excavate three test pits with a backhoe. Samples will be collected at approximately 2-foot intervals to a maximum depth of about 12 feet below the ground surface (or the maximum reach of the backhoe). The planned locations for the test pits are as follows:

- At the sump where the decontamination pad drain pipe discharged 
- At the sump where the sewer pipe discharged

- The soil near the northeast corner of the decontamination pad where runoff from decontamination effluent would have most likely ponded

- Collect soil samples for laboratory analysis as follows:

- Soil samples will be collected at the gravel-soil interface in each of the sump test pits. Soil samples will be collected from each test pit, at approximately 2-foot depth intervals until a sample has been collected below field-screening levels or to the maximum reach of the backhoe (about 12 feet below the ground surface or about 6 feet below the gravel/soil interface). At a minimum two depth intervals will be sampled.

- At the test pit near the northeast corner of the decontamination pad, soil sampling will begin at ground surface and continue at approximately 2-foot depth intervals until a sample has been collected below field-screening levels or to the maximum reach of the backhoe (about 12 feet below ground surface). At a minimum two depth intervals will be sampled.

- If field-screening results exceed field-screening levels at 12 feet below ground surface (or the maximum reach of the backhoe), then sampling will stop and the investigation will be rescoped.

- If contaminants of potential concern are not detected above preliminary action levels, a Corrective Action Decision Document/Closure Report will be prepared.

- Field screen for VOCs using a headspace technique with a photoionization detector.

- Field survey for radioactivity using an Electra alpha/beta scintillator, a sodium iodide detector, or intrinsic germanium detector (or equivalent).

- Conduct a geophysical survey to locate the piping, as necessary.

- Conduct a video survey to locate breaches in piping, as necessary.

- Conduct laboratory analysis for gamma emitters, total volatile organic compounds, total semivolatile organic compounds, total petroleum hydrocarbons-diesel range organics, Resource Conservation and Recovery Act metals, total pesticides, and polychlorinated biphenyls.

- Collect and submit quality control samples as prescribed in the Quality Assurance Project Plan. 
- Collect additional samples should the following occur:

- Field-screening levels or preliminary actions levels are exceeded and contamination needs to be further delineated.

- Data are insufficient for a corrective action decision document evaluation.

- More data are needed for waste management purposes.

- Site Supervisor determines it to be necessary.

Under the Federal Facility Agreement and Consent Order, the Corrective Action Investigation Plan will be submitted to the Nevada Division of Environmental Protection for approval. Field work will be conducted following approval of the plan. The results of the field investigation will support a defensible evaluation of corrective action alternatives in the Corrective Action Decision Document. 


\subsection{Introduction}

This Corrective Action Investigation Plan (CAIP) has been developed in accordance with the Federal Facility Agreement and Consent Order (FFACO) that was agreed to by the U.S. Department of Energy, Nevada Operations Office (DOE/NV); the State of Nevada Division of Environmental Protection (NDEP); and the U.S. Department of Defense (FFACO, 1996). The CAIP is a document that provides or references all of the specific information for investigation activities associated with Corrective Action Units (CAUs) or Corrective Action Sites (CASs). According to the FFACO, CASs are sites potentially requiring corrective action(s) and may include solid waste management units or individual disposal or release sites (FFACO, 1996). Corrective Action Units consist of one or more CASs grouped together based on geography, technical similarity, or agency responsibility for the purpose of determining corrective action(s).

This CAIP contains the environmental sample collection objectives and the criteria for conducting site investigation activities at the CAU 252, CAS 25-07-02, Area 25 Engine Test Stand-1 (ETS-1) Decontamination Pad at the Nevada Test Site (NTS). For purposes of this discussion, this site will be referred to as either CAU 252 or the ETS-1 Decontamination Pad. The NTS is approximately 65 miles (mi) northwest of Las Vegas, Nevada (Figure 1-1). The ETS-1 Decontamination Pad was designed as a mobile radiation checkpoint and for vehicle decontamination (Figure 1-2). The ETS-1 Decontamination Pad is located at the intersection of Road H and Road K south of the ETS-1 facility (Pan Am, 1966; Pan Am, 1968). The CAU 252 site includes a concrete decontamination pad with a drain, a gravel filled sump, two concrete trailer pads, and utility boxes.

\subsection{Purpose}

The purpose for the corrective action investigation of the ETS-1 Decontamination Pad is to determine the nature and extent of contaminants of potential concern (COPCs). This investigation needs to provide sufficient information and data to develop appropriate corrective action alternatives for CAU 252, including closure in place and clean closure, which will be evaluated in the Corrective Action Decision Document (CADD). The resulting data will permit DOE/NV to make informed decisions about the future disposition of CAU 252. 


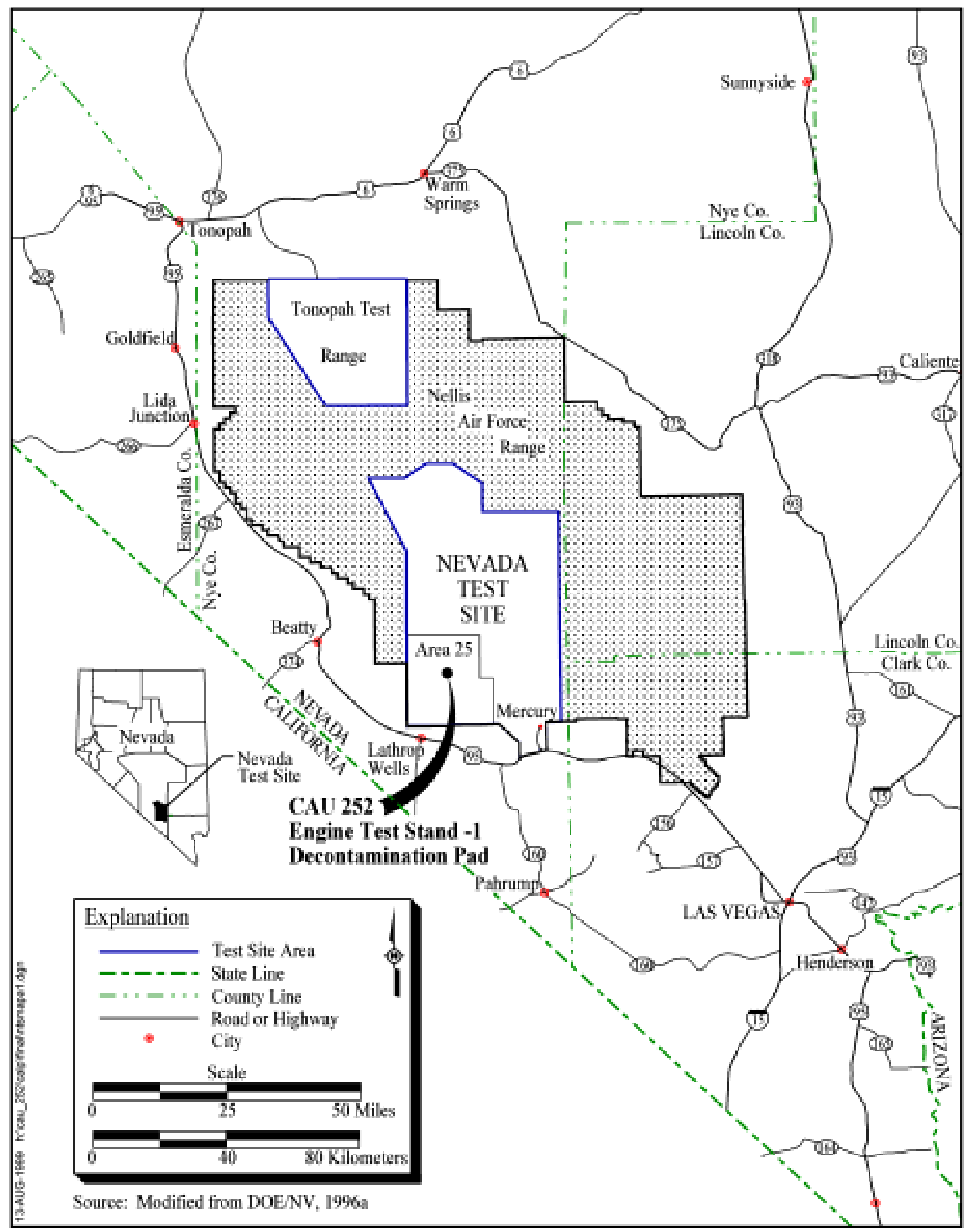

Figure 1-1

Nevada Test Site and CAU 252 Engine Test Stand -1 Decontamination Pad Location Map, Nevada 


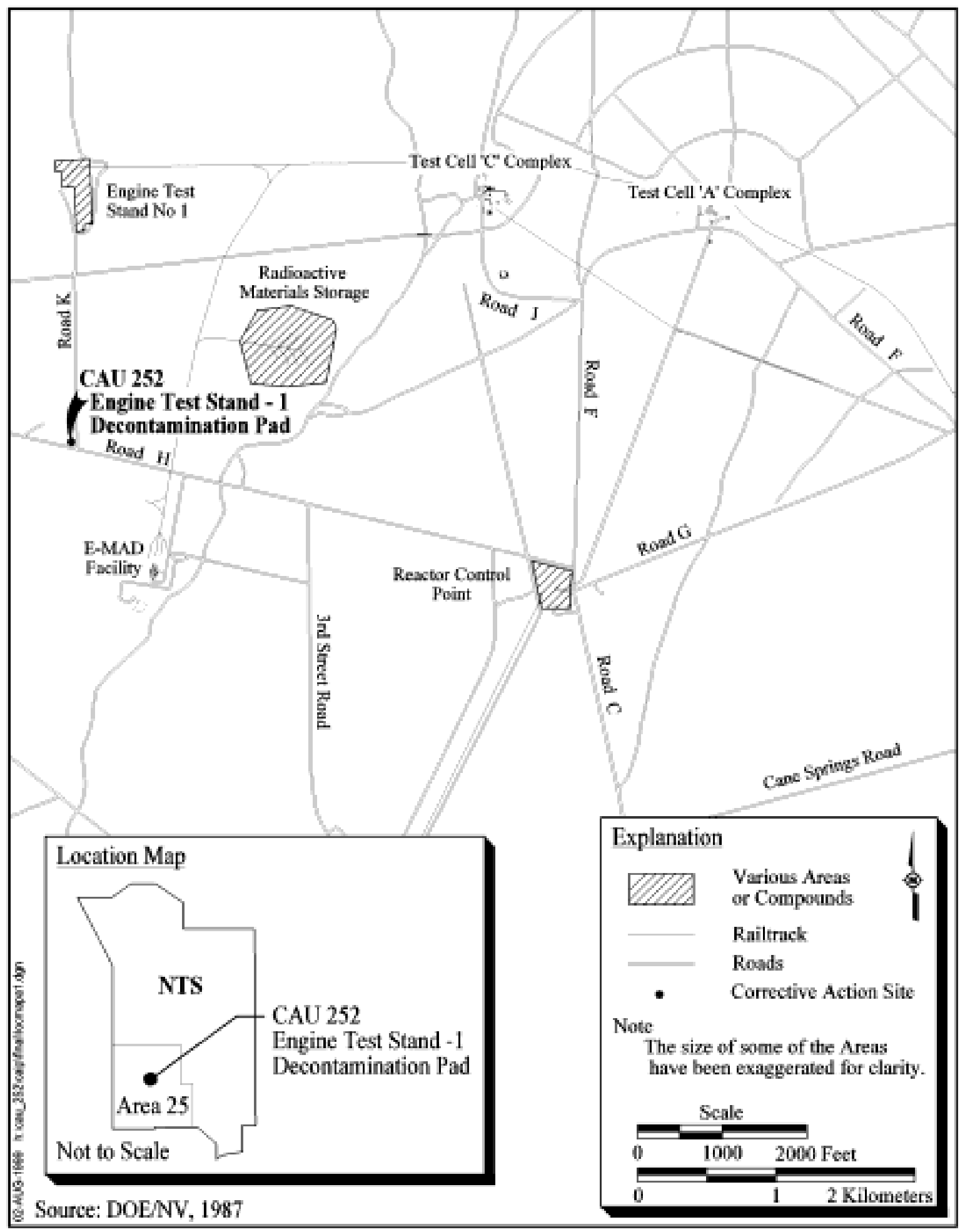

Figure 1-2

CAU 252, Area 25, Engine Test Stand-1 Decontamination Pad Location, Nevada Test Site 
This CAIP was developed using the U.S. Environmental Protection Agency (EPA) Data Quality Objectives (DQOs) (EPA, 1994) process to clearly define the goals, establish the DQOs for collecting environmental data, and to design a data collection program that will satisfy these goals. A DQO scoping meeting was held on April 28, 1999. A brief summary of the DQOs is presented in Section 3.4 of this CAIP, a detailed summary of the DQO process and results is included in Appendix A.

\subsection{Scope}

The scope of this CAIP is to resolve the problem statement identified during the DQO process (see Appendix A) which states that radioactive and potentially hazardous wastes may have been released at CAU 252. The existing information about the nature and extent of contamination is insufficient to evaluate and select a preferred corrective action. Therefore, the scope of the corrective action investigation for the ETS-1 Decontamination Pad includes the following tasks:

- Determine if COPCs are present

- Collect soil samples from biased, worst-case locations using a backhoe.

- Utilize headspace field-screening methods to determine the presence of volatiles and assist in guiding the sampling investigation.

- Utilize field-survey techniques to determine the presence of radionuclides and assist in guiding the sampling investigation.

- Identify the types and concentrations of COPCs through laboratory analytical methods and techniques.

- If COPCs are above field-screening levels (FSLs) and/or preliminary action levels (PALs), additional sampling (i.e., step-outs) may be required to delineate vertical and/or lateral extent. Additional sampling may be conducted with direct-push technology (or other approved sampling method) if the backhoe is inadequate for sampling needs. 


\subsection{CAIP Contents}

Section 1.0 of this CAIP provides an introduction to this project, including the purpose and scope for this corrective action investigation. The remainder of the document details the investigation strategy. The FFACO (1996) requires that CAIPs address the following elements:

- Management

- Technical aspects

- Quality assurance

- Health and safety

- Public involvement

- Field sampling

- Waste management

The managerial aspects of this project are discussed in the DOE/NV Project Management Plan (DOE/NV, 1994) and the site-specific Field Management Plan that will be developed prior to field activities. A facility description is presented in Section 2.0. The technical aspects of this CAIP are contained in Section 3.0 and Section 4.0 of this document and in the DQO summary presented in Appendix A. General field and laboratory quality assurance and quality control (QA/QC) issues, including collection of quality control (QC) samples are presented in the Industrial Sites Quality Assurance Project Plan (QAPP) (DOE/NV, 1996b), as well as in this CAIP.

The generic health and safety protocol to be followed for this project is documented in applicable sections of the Environmental Restoration Project Health and Safety Plan (DOE/NV, 1998) and will also be supplemented with a site-specific health and safety plan which will be written prior to commencement of field activities. In addition, as required by the U.S. Department of Energy (DOE) Integrated Safety Management System, these documents outline the requirements for protecting the health and safety of the workers and the public, and some procedures for protection of the environment. Site personnel will take every reasonable step to reduce or eliminate the possibility of injury, illness, or accident, and to protect the environment during all project activities. The following will be taken into consideration when evaluating the hazards and associated control procedures for the field activities:

- Potential hazards to site personnel and the public include, but are not limited to, radionuclides, chemicals (such as Resource Conservation and Recovery Act [RCRA] metals, volatile organic compounds [VOCs], and semivolatile organic compounds [SVOCs]), adverse and rapidly 
changing weather, remote location, motor vehicle and heavy equipment operation, and excavations.

- Proper training of all site personnel to recognize and mitigate the anticipated hazards.

- Work controls to reduce or eliminate the hazards including engineering controls, substitution of less hazardous materials, and personal protective equipment (PPE).

- Occupational exposure monitoring to prevent overexposure to hazards, including chemical and/or physical agents.

- Use of the "as low as reasonably achievable" (ALARA) principle when dealing with radiological hazards.

- Emergency and contingency planning and communication to include medical care and evacuation, decontamination and spill control measures, and appropriate notification of project management.

No CAU-specific public involvement activities are planned at this time; however, an overview of the public involvement process is documented in the Public Involvement Plan in Appendix V of the FFACO (1996). Waste management issues are discussed in Section 5.0. The project schedule and records availability information are discussed in Section 6.0, and project references are provided in Section 7.0. 


\subsection{Facility Description}

Corrective Action Unit 252 (ETS-1 Decontamination Pad) is comprised of one CAS, the Decontamination Pad (25-07-04). The ETS-1 facility was used as a test stand for nuclear rocket tests (SNPO, 1970). The ETS-1 facility is included as part of the Nuclear Rocket Development Station (NRDS) in Area 25 of the NTS, which was operational primarily between 1959 and 1973 (Bernhardt et al., 1974; DOE/NV, 1984). The NRDS complex consisted of several buildings, test facilities, and support systems used for the development and testing of nuclear rocket engines. The ETS-1 Decontamination Pad is located south of the ETS-1 facility and was designed to be used as a mobile radiation check point and for vehicle decontamination (Figure 2-1) (Pan Am, 1966; Pan Am, 1968).

General background information pertaining to the history of the NTS and Area 25, a geologic assessment, and an overview of the area hydrogeology including depths to groundwater are provided in the Site Characterization Plan, Yucca Mountain Site (DOE, 1988).

\subsection{Physical Setting}

Topographically, Area 25 is an intermontane valley bordered by highlands on all sides, except for a large drainage outlet to the southwest. Elevations range from 3,400 to 5,600 feet (ft). The dominant plant community is Larrea-Ambrosia associated with a transition zone between the Mojave and Great Basin Deserts (DRI, 1988).

The NRDS area is located in Jackass Flats which is underlain by alluvium, colluvium, and volcanic rocks of Cenozoic age and, at greater depth, by sedimentary rocks of Paleozoic age. The alluvium and the colluvium lie above the saturated zone throughout nearly all of Jackass Flats. The Paleozoic sedimentary rocks contain limestone and dolomite units that are excellent water producers elsewhere; however, these units are too deep in Jackass Flats to be economic water sources. The only important water producing unit known in the vicinity of the NRDS is a welded-tuff aquifer, the Topopah Spring Member of the Paintbrush tuff (DRI, 1988; SNPO, 1970).

Three water supply wells are within the NRDS, Wells J-11, J-12, and J-13. Yucca Flat, Frenchman Flat, and Jackass Flats are believed to be hydraulically connected, with groundwater moving along 


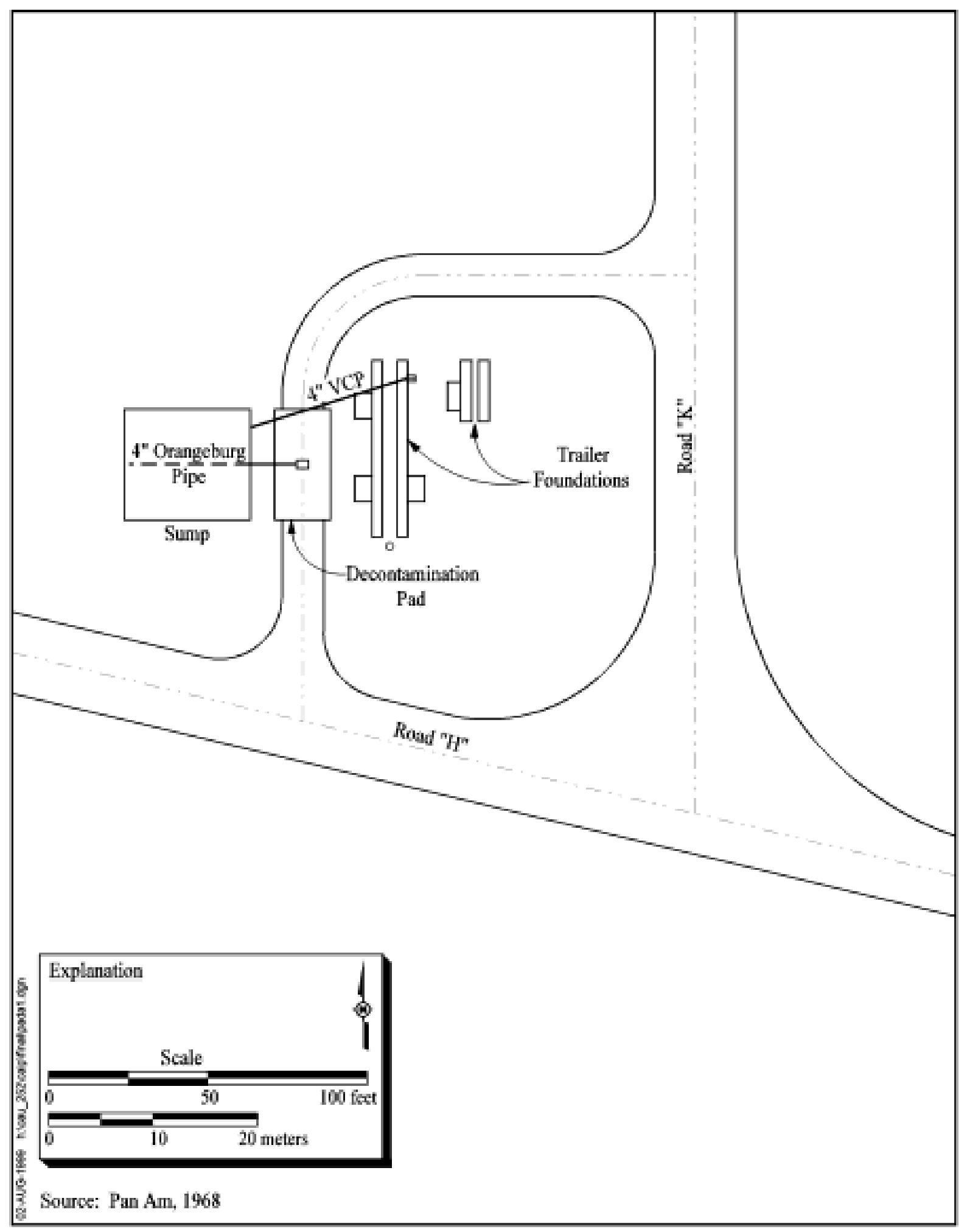

Figure 2-1

CAU 252, Area 25 Engine Test Stand-1 Decontamination Pad Layout 
fracture zones in the carbonates. It is thought that the present groundwater is a result of rainfall in the past, and that no significant recharge of groundwater is occurring now (SNPO, 1970).

Surface water is ephemeral and is a function of variations in annual climate patterns. Climate in this area is affected by the rain shadow of the Sierra Nevada. The average annual rainfall for Jackass Flats is approximately 4 inches (in.) (DOE, 1988). Approximately 65 percent of the precipitation for the area occurs between October and April as a result of Pacific Coast storms (DOE, 1988). Summer showers are generally isolated and precipitation is variable. Occasionally, storms move directly from the Gulf of California, resulting in wide-spread heavy rain (DOE, 1988).

\subsection{Operational History}

The ETS-1 facility, constructed in 1966, was part of the NRDS complex and used to test nuclear rockets. The ETS-1 Decontamination Pad and mobile radiation check point was built in 1968. The NRDS complex ceased primary operations in 1973. The CAU 252 investigation area, which measures approximately $115 \mathrm{ft}$ by $60 \mathrm{ft}$, includes the following:

- A concrete decontamination pad that measures approximately $35 \mathrm{ft}$ long by $15 \mathrm{ft}$ wide with a small grated drain ( $1.5 \mathrm{ft}$ by $0.5 \mathrm{ft}$ ); the decontamination pad slopes downward to the northeast

- A gravel-filled sump that measures approximately $31 \mathrm{ft}$ long by $35 \mathrm{ft}$ wide; the surface of the sump is below the general area topography

- A pair of concrete trailer pads that measure approximately $55 \mathrm{ft}$ by $3 \mathrm{ft}$ and a smaller concrete pad for the trailer tongue; this trailer had a sewer drain that connected to the sump (Figure 2-1)

- A pair concrete trailer pads that measure approximately $18 \mathrm{ft}$ by $3 \mathrm{ft}$ and a smaller concrete pad for the trailer tongue (Figure 2-1)

- Several utility boxes

\subsection{Waste Inventory}

The DQO process evaluated available information, and a list of potential contaminants was developed (Appendix A). Based on its intended use as a mobile radiation checkpoint and for vehicle decontamination, the potential contaminants are radionuclides, VOCs, SVOCs, total petroleum hydrocarbons (TPH) - diesel range organics, RCRA metals, pesticides, and polychlorinated biphenyls 
(PCBs). The radiological contamination, if present, would result from the decontamination of vehicles at the site. Volatile organic compounds, SVOCs, and TPH-diesel may be present from the potential use of decontamination solvents and/or vehicle fuel. RCRA metals may result due to the potential to accumulate from the vehicles themselves. Pesticides were added to the COPC list because they were identified at similar sites in the Area 25 NRDS complex (i.e., CAU 240 Area 25 Vehicle Washdown Stations). Any pesticide occurrence may be the result of pesticide application around the pads. Polychlorinated biphenyls are also included because they were identified in small concentrations in the preliminary sample analytical results (see Section 2.5).

\subsection{Release Information}

Vehicle decontamination effluent is the source of potential contamination in the soil near the northeast corner of the decontamination pad and within the sump. The decontamination pad slopes downward to the northeast and decontamination effluent could have runoff the pad and ponded on the soil near the northeast corner of the pad. Additionally, there are two pipes that were designed to discharge to the sump. The decontamination pad drain pipe consists of vitrified clay and perforated pipe (orangeburg pipe) that discharged along the center of the sump (Figure 2-1). The perforated pipe is about $2 \mathrm{ft}$ below the gravel-fill surface. Liquid that was discharged to the pipe would percolate out of the pipe and into the gravel fill and subsequently into the subsurface soil. The larger trailer pad has a vitrified clay sewer pipe that discharged to the northeast corner of the sump (Figure 2-1).

The primary driving force for any vertical migration of COPCs would be the liquid discharged to the sump. No odor or surface staining on the decontamination pad was observed by the field personnel (Forsgren, 1998). Bechtel Nevada (BN) conducted a radiological survey with an Electra scintillator at the ETS-1 site on June 29, 1999 (BN, 1999). During the survey, pieces of an old yellow and magenta rope were found on the ground north and south of the sump, and an old radiological sign was found west of the sump. The radiological survey results did not exceed or meet RADCON requirements (DOE/NV, 1996c) for posting (BN, 1999).

No documentation has been located at this time that describes the usage of the ETS-1 Decontamination Pad. Therefore, the quantities of liquids that could have been generated from decontamination activities or discharged to the sump for this site are unknown. 


\subsection{Investigative Background}

A preliminary surface-soil sample (ERS00044) was collected by IT Corporation on August 15, 1997, from the soil near the northeast corner of the decontamination pad (Forsgren, 1998). The intent of the preliminary sample was to collect soil considered most likely to be contaminated to determine the COPCs. The sample was analyzed by an off-site laboratory for VOCs, SVOCs, TPH-diesel range organics, RCRA metals, PCBs, gross alpha/beta, and gamma emitters (Forsgren, 1998). Although the analytical results for the sample identified both chemical and radioactive constituents above detection limits, the results did not indicate the presence of any COPCs above EPA Region IX Industrial Soil Preliminary Remediation Goals (PRGs) (EPA, 1998). These analytical results were used to identify COPCs for this corrective action investigation.

In accordance with the DOE/NV National Environmental Policy Act (NEPA) compliance program, a NEPA checklist shall be completed prior to commencement of site investigation activities at CAU 252. This checklist requires DOE/NV projects to evaluate their proposed project against a list of several potential environmental impacts. These include, but are not limited to, air quality, chemical use, waste generation, noise level, and land use. Completion of the checklist results in a determination of the appropriate level of NEPA documentation by the DOE/NV NEPA Compliance Officer. 


\subsection{Objectives}

The DQOs (see Appendix A) are qualitative and quantitative statements (EPA, 1994) that specify the quality of the data required to support potential corrective action alternatives for the ETS-1

Decontamination Pad investigation. The DQOs were developed to clearly define the purpose(s) for which environmental data will be used and to design a data collection program that will satisfy these uses (Section 4.1). The formulation of a conceptual site model was used as an aid for the development of DQOs for the site. The conceptual site model for the ETS-1 Decontamination Pad sampling activities is presented in Section 3.1.

\subsection{Conceptual Site Model}

The conceptual site model defines the expected nature and extent of contamination within CAU 252. The conceptual site model for this CAU is based on assumptions formulated on information presented in Section 2.0 and discussed during the DQO process. The model is used to identify an appropriate sampling strategy and data collection methods. The conceptual site model and assumptions developed in the DQO process are presented in Appendix A and are summarized as follows:

- Contaminants of potential concern, if present, could have been released into the soil near the northeast corner of the decontamination pad and/or into the sump during the decontamination of vehicles at the site.

- Vertical extent of COPCs is expected to be less than $12 \mathrm{ft}$ below ground surface (bgs). The assumed vertical extent is based in part on investigative and analytical results of CAU 240, Area 25 Vehicle Washdown Pads which show contamination to be within $3 \mathrm{ft}$ to $5 \mathrm{ft}$ bgs (Bordelois, 1999). Also, the vertical extent of contamination would be affected by the arid environment, high evaporation, soil type, low annual precipitation, and the physical nature of the COPCs that are not conducive to the downward migration of contaminants.

- Lateral extent of COPCs is expected to be limited to the sump area or near the northeast corner of the decontamination pad. The decontamination pad slopes downward to the northeast. Runoff from decontamination activities would have most likely ponded on the soil near the northeast corner of the pad. The sump area and the soil near the northeast corner of the decontamination pad are considered to be the worst-case locations for contamination, if present. 
- Groundwater is unlikely to be impacted from potential contaminant releases because the depth-to-water near the ETS-1 site for three NTS wells, J-11, J-12, and J-13, is approximately 1,040 ft, $740 \mathrm{ft}$, and $928 \mathrm{ft}$, respectively (La Camera et al., 1999).

\subsection{Contaminants of Potential Concern}

A list of COPCs for the ETS-1 Decontamination Pad was determined based on a review of site history documentation, subjective process knowledge, preliminary analytical results, and inferred activities associated with the CAU. Based on this information, the following COPCs have been identified:

- Gamma emitters

- Total VOCs

- Total SVOCs

- RCRA metals

- TPH-diesel range organics

- Total pesticides

- $\mathrm{PCBs}$

All soil samples collected from the test pits will be submitted for laboratory analyses for the specified COPCs. Additional samples may also be collected for waste management purposes. If additional sampling needs to be conducted at the site, the COPC list may be reduced or expanded based on analytical results from the test pit samples. The COPC field-screening methods and levels, analytical methods, and PALs are shown in Table A.3-1 and Table A.3-2 in Appendix A.

\subsection{Preliminary Action Levels}

The following subsections describe the FSLs for on-site field-screening methods and PALs for analytical methods that will be used to determine the presence of contamination and guide the collection of environmental samples.

\subsubsection{Field-Screening Levels}

The following FSLs will be used during the ETS-1 Decontamination Pad corrective action investigation:

- The VOC headspace (e.g., photoionization detector [PID]) FSL is established at 20 parts per million (ppm) or 2.5 times background, whichever is greater. 
- Radiation FSLs are established as the mean background activity level plus two times the standard deviation of the mean background activity level (to be determined prior to start of field activities and monitored during sampling).

Field screening will provide on-site measurement of VOCs and field surveys will be conducted for on-site measurement of radionuclides. The COPC concentrations that exceed FSLs indicate potential contamination at that sample location. Field-screening results will be used as an initial indicator of potential contamination and will be used assist in guiding the sampling investigation.

\subsubsection{Chemical Preliminary Action Levels}

Laboratory analysis will provide quantitative measurement of the chemical COPCs. The data obtained from laboratory analysis will be used to support corrective action decision recommendations for CAU 252 in the CADD. The analytical methods and minimum reporting limits for each COPC are presented in Appendix C. Analytical results will be compared to the following PALs to evaluate the need for possible corrective actions:

- NDEP Corrective Action Regulations (NAC, 1998b); for purposes of this investigation, the risk-based industrial soil PRGs for EPA Region IX (EPA, 1998) will be used as the PALs.

- $\mathrm{TPH}$ concentrations above the TPH limit of $100 \mathrm{mg} / \mathrm{kg}$ per the Nevada Administrative Code (NAC) 445A.2272 (NAC, 1998b)

The comparison of laboratory results to PALs will be discussed in the CADD. Laboratory results above PALs would indicate the presence of COPCs at levels that may require corrective action. The evaluation of potential corrective actions and the justification for a preferred corrective action will be included in the CADD based on the results of this field investigation.

\subsubsection{Radiological Preliminary Action Levels}

The PALs for radionuclides are isotopic specific and are defined as the maximum concentration for that isotope found in environmental samples taken from undisturbed background locations. Environmental samples will be taken within the vicinity of CAU 252. These samples will be analyzed and compared with the results for environmental samples taken from other undisturbed background locations in Area 25. In addition, the radionuclide concentrations in the CAU 252 and 
Area 25 background samples will be compared with the radionuclide concentrations found in environmental samples taken from undisturbed background locations in the vicinity of the NTS, presented in McArthur and Miller (1989) and Atlan-Tech (1992). The PAL for each isotope will be the maximum concentration of that isotope found in any of the samples taken from the undisturbed background locations described above. For soil matrix, the minimum reporting limit for Cobalt-60, Cesium-137, and Niobium-94 is 0.4 picocuries per gram (Adams, 1999). For water matrix, the minimum reporting limit for Cobalt-60 is 50 picocuries per liter, Cesium-137 is 10 picocuries per liter, and for Niobium-94 is 20 picocuries per liter (Adams, 1999).

\subsection{DQO Process Discussion}

During the DQO discussions for CAU 252, a biased sampling approach was identified for this site. Near-surface and subsurface sampling will be conducted at the suspected worst-case areas: the sump and to soil near the northeast corner of the decontamination pad (see Section 4.1 and Appendix A). Details about the COPC analytical methods prescribed through the DQO process are provided in Table A.3-1 of Appendix A. The precision and accuracy requirements and reporting limits for these analytical methods are presented in Appendix C. 


\subsection{Field Investigation}

This section of the CAIP contains the sampling approach for investigation of the CAU 252, Area 25 ETS-1 Decontamination Pad. All sampling activities will be conducted following the guidelines specified in the Industrial Sites QAPP (DOE/NV, 1996b) and other applicable, approved procedures. Quality assurance and quality control requirements for field and laboratory environmental sampling are also contained in the Industrial Sites QAPP (DOE/NV, 1996b). The general sampling strategy will focus on answering the problem question: "Is the site contaminated?" The planned sampling locations are biased to the potential worst-case contamination areas. Field screening, field surveys, and laboratory analyses are the primary investigation tools for determining the presence and nature of COPCs.

\subsection{Technical Approach}

The following main activities will be conducted during the site investigation:

- Conduct a utility survey prior to excavation activities.

- Determine radiological field-screening levels using an Electra alpha/beta scintillator, a sodium iodide detector, or intrinsic germanium detector (or equivalent) by taking 20 background sample readings and calculating the mean plus two standard deviations.

- Remove the gravel-fill from test pit locations in the sump with a backhoe prior to sampling soil in the sump.

- Excavate three test pits with a backhoe. Samples will be collected at approximately 2-ft intervals to a maximum depth of about $12 \mathrm{ft}$ below the ground surface (or the maximum reach of the backhoe). The planned locations for the test pits are as follows:

- At the sump where the decontamination pad drain pipe discharged

- At the sump where the sewer pipe discharged

- The soil near the northeast corner of the decontamination pad where runoff from decontamination effluent would have most likely ponded 
- Collect soil samples for laboratory analysis as follows:

- Soil samples will be collected at the gravel-soil interface in each of the sump test pits. Soil samples will be collected from each test pit, at approximate 2 -ft sample depth intervals until a sample has been collected below field-screening levels or to the maximum reach of the backhoe (about $12 \mathrm{ft}$ bgs or about $6 \mathrm{ft}$ below the gravel/soil interface). At a minimum two depth intervals will be sampled.

- At the test pit near the northeast corner of the decontamination pad soil sampling at this location will begin at ground surface and continue at approximate 2-ft sample depth intervals until a sample has been collected below field-screening levels or to the maximum reach of the backhoe (about $12 \mathrm{ft} \mathrm{bgs).} \mathrm{At} \mathrm{a} \mathrm{minimum} \mathrm{two} \mathrm{depth} \mathrm{intervals} \mathrm{will} \mathrm{be} \mathrm{sampled.}$

- If field-screening results exceed field-screening levels at $12 \mathrm{ft}$ bgs (or the maximum reach of the backhoe), then sampling will stop and the investigation will be rescoped.

- If COPCs are not detected above PALs, then prepare a CADD/Closure Report (CR).

- Field screen for VOCs using the headspace technique with a photoionization detector.

- Field survey for radioactivity using an Electra alpha/beta scintillator, a sodium iodide detector, or intrinsic germanium detector (or equivalent).

- Conduct a geophysical survey to locate the piping, as necessary.

- Conduct a video survey to locate breaches in piping, as necessary.

- Conduct laboratory analysis for gamma emitters, total VOCs, total SVOCs, TPH-diesel, RCRA metals, total pesticides, and PCBs.

- Collect and submit quality control samples as prescribed in the QAPP.

- Collect additional samples should the following occur:

- Field-screening levels or preliminary actions levels are exceeded and contamination needs to be further delineated.

- Data are insufficient for a corrective action decision document evaluation.

- Needed for waste management purposes.

- Site Supervisor determines it to be necessary.

In the following sections, the components of the field investigation are described in greater detail. 


\subsection{Field Activities}

Sampling associated with CAU 252 will be focused within the sump area (west of the ETS-1 Decontamination Pad) and in the soil near the northeast corner of the decontamination pad. The gravel-fill within the sump area will be removed from the location of the planned test pits. All equipment which contacts soil to be sampled will be decontaminated in accordance with approved procedures. The environmental soil samples collected for laboratory analysis will be from fresh media. Samples will be collected with highest priority given to those that will be analyzed for VOCs. When volatilization of COPCs is not a concern, samples will be collected with priority given to those with the shortest hold times prior to analysis.

Records will be maintained of the general physical characteristics of the soil, field-screening measurements, and all other relevant data. Pertinent and required sampling information (e.g., date, time, sample interval) will be documented in accordance with the Industrial Sites QAPP (DOE/NV, 1996b). Approved chain-of-custody procedures will be followed to ensure data defensibility.

\subsubsection{Test Pit Excavation and Soil Sampling}

A backhoe will be used to remove the gravel from the sump and to excavate three test pits at the site. Two test pits will be excavated in the sump where the trailer sewage pipe and decontamination pad drain pipe discharged into the sump (Figure A.1-1 of Appendix A). The third test pit will be excavated near the northeast corner of the decontamination pad. Soil sampling in the sump test pits will begin at the gravel/soil interface and continue at approximately 2 - $\mathrm{ft}$ depth intervals until a sample has been collected below FSLs. The maximum sampling depth will be $12 \mathrm{ft}$ bgs (about $6 \mathrm{ft}$ below the gravel/soil interface for the sump test pits) or to the maximum reach of the backhoe. Soil sampling for the test pit near the northeast corner of the decontamination pad will begin at the ground surface and continue at approximately 2-ft depth intervals until a sample has been collected below FSLs or to the maximum reach of the backhoe (about $12 \mathrm{ft}$ bgs). At a minimum, two depth intervals will be sampled at each test pit.

If COPCs (i.e., VOCs or radionuclides) are detected above the FSLs at the maximum sample depth, the investigation will stop and be rescoped. The soil samples collected from each sample interval in 
the test pits will be submitted for laboratory analysis. The soil samples will be analyzed for gamma emitters, total VOCs, total SVOCs, TPH-diesel range organics, RCRA metals, total pesticides, and PCBs.

If FSLs or PALs are exceeded at the test pits, additional (step-out) sampling may be conducted to further delineate the lateral and vertical extent of COPCs. The location and depth of the samples will be based on the results of the FSLs, PALs, and/or at the discretion of the Site Supervisor. Additional sampling, if necessary, will be conducted with a backhoe, direct-push, or other approved sampling method. Direct-push technology may be also used to collect soil samples should the backhoe be inadequate for sample collection. Additional sampling may be conducted should the following occur:

- Lateral and vertical extent of contamination is not adequately delineated.

- Laboratory analytical results are inadequate for evaluation in the CADD.

- Data is not sufficient to make a waste determination.

\subsubsection{Video/Geophysical Survey}

Based on the existing information and a preliminary site evaluation, a video/geophysical survey of the drains and pipelines does not appear to be necessary at this time. However, video/geophysical survey equipment will be available during the excavation of the test pits in case the drains and pipelines warrant this type of assessment. Should a video survey be deemed necessary, the Site Supervisor will determine if the survey should be performed from the drain to the sump or in the reverse direction. An optional radiation detector may be included with the camera and cable system for the video survey to further assess the drainage system, if necessary. Any decisions regarding the video/geophysical survey will be made at the discretion of the Site Supervisor, Project Manager, and DOE/NV representative.

\subsubsection{Field Screening and Field Surveys}

Field screening for VOCs and field surveys for radiological activity will be performed for all samples. The field-screening results will be used as follows:

- Guiding the sampling investigation by providing semiquantitative measurements of the soil conditions 
- Provide information to establish the maximum depth of COPCs and the need for additional (step-out) sampling

- Monitoring the health and safety of personnel

- Waste management decisions

Field screening for TPH will not be conducted because of the potential for radionuclides to be present thereby possibly generating mixed waste. Field screening for VOCs will be performed using a PID and headspace techniques. Field surveying for radioactivity will be performed using an Electra alpha/beta scintillator, sodium iodide detector, and/or intrinsic germanium detector (or equivalent).

\subsubsection{Quality Control Samples}

Quality control samples will be collected as required by the Industrial Sites QAPP (DOE/NV, 1996b). These samples will include trip blanks, equipment blanks, field blanks, field duplicates, and matrix spike/matrix spike duplicate (MS/MSD) samples. Except for trip blanks, all QC samples will be analyzed for applicable parameters, trip blanks will only be analyzed for VOCs. The following quality control samples will be collected:

- Field Blanks - one per 20 samples submitted to the laboratory

- Equipment Blanks - an equipment rinsate blank will be submitted to the laboratory for each different type of sampling activity and/or decontamination process.

- Field Duplicates - one per 20 samples per matrix submitted to the laboratory

- $\mathrm{MS} / \mathrm{MSD}$ - one per 20 samples per matrix submitted to the laboratory

- Trip Blanks - one per shipping container (cooler) if analyzing for VOCs 


\subsection{Waste Management}

Management of investigation-derived waste (IDW) will be based on regulatory requirements, field observations, process knowledge, and the results of laboratory analysis of ETS-1 Decontamination Pad investigation samples. Additional analyses may be requested for waste management purposes. Administrative controls (decontamination procedures and the characterization strategy) will minimize waste generated during the investigation.

Solid materials other than soil wastes are potentially contaminated waste only by virtue of contact with potentially contaminated media. The same is true for the decontamination rinsate. Therefore, sampling and analysis of the IDW, separate from analyses of site characterization samples, will generally not be required. In some cases rinsate may need to be analyzed separately to determine final disposition. The data generated as a result of site characterization will be used to assign the appropriate waste type (i.e., sanitary, hazardous, low-level radioactive [LLW], or mixed) to the IDW with the exception noted in Section 5.3.

Sanitary, hazardous, LLW, and/or mixed waste, if generated, will be managed and disposed of in accordance with DOE Orders, U.S. Department of Transportation (DOT) regulations, RCRA regulations, Nevada Revised Statutes (NRS, 1998), and agreements and permits between the DOE and the NDEP.

In the following sections, operational requirements are provided for managing sanitary, hazardous, LLW, and mixed wastes. However, when the waste is initially generated, it will be managed according to mixed waste requirements until laboratory analyses are received and a final waste determination is made.

\subsection{Waste Minimization}

Corrective action investigation activities have been planned to minimize the amount of IDW generated. Decontamination activities are planned to minimize the use of rinsate; decontamination materials will consist of detergent, water, and wipes. Disposable sampling equipment and PPE, will be segregated to the greatest extent possible to avoid generation of hazardous, radioactive, and/or mixed waste. 


\subsection{Potential Waste Streams}

Historical records and process knowledge indicate that potentially hazardous materials and/or radioactive materials may have been generated at the site. There is a potential that sanitary, LLW, hazardous, mixed, and/or hydrocarbon wastes will be generated at the site. Wastes generated during the investigation activities may include, but are not limited to, the following:

- Contaminated disposable or reusable sampling equipment (such as plastic, paper, sample containers, aluminum foil, spoons, scoops, and bowls)

- Decontamination rinsate

- Spent PPE which was contaminated during excavation and sampling activities

- Contaminated soil

For administrative purposes, this waste will be managed in three waste streams: soil, contaminated solid trash, and liquid wastes (such as decontamination rinsate). Segregation will occur within each waste stream based on sample location. For example, the soil waste and decontamination rinsate will be segregated. Waste will be traceable to its source and to individual samples.

\subsection{Investigation-Derived Waste Management}

All waste generated through the performance of the field activities at the ETS-1 Decontamination Pad will be managed in accordance with the requirements outlined in this CAIP, waste minimization and pollution prevention objectives, and waste management programs.

To allow for the segregation of radioactive and nonradioactive waste and materials, radiological swipe surveys or screening for fixed radiation may be conducted on reusable sampling equipment, the PPE, and disposable sampling equipment waste streams exiting from within the controlled area. Contamination limits, as defined in Table 2-2 of the NV/YMP Radiological Control Manual (DOE/NV, 1996c), shall be used to determine if such materials may be declared nonradioactive. Once a radiological or nonradiological determination has been made for a particular waste stream, a sanitary or hazardous waste determination will be made. The final disposition of such wastes will be determined by evaluating the analytical results of acquired soil samples. Management requirements for sanitary, LLW, hazardous, or mixed wastes are discussed further in the following sections. 


\subsubsection{Sanitary Waste}

Sanitary waste, generated outside the controlled area, will be contained in plastic bags, dumpsters, or packages and transported to an NTS-managed sanitary waste landfill.

\subsubsection{Low-Level Radioactive Waste}

Low-level radioactive waste, if generated, will be managed in accordance with DOE Orders, the contractor-specific waste certification program plan and the Nevada Test Site Waste Acceptance Criteria (NTSWAC) (DOE/NV, 1997). Packages containing soil, PPE and disposable sampling equipment, and rinsate (when full) shall be staged at a designated Radioactive Materials Area or a Radioactive Control Area pending certification and disposal under NTSWAC requirements (DOE/NV, 1997). The PPE and disposable sampling equipment shall be placed in clear plastic bags marked with the date and an associated sample location number. The bags will be tagged with a contractor-specific waste tracking tag and logged in the contractor-specific waste management logbook. The DOE-compliant packages shall be labeled "Hazardous Waste Pending Analysis" and "Radioactive Material Pending Analysis," and will be locked or fitted with tamper-indicating devices (TIDs). Traceability shall be maintained by assigning unique waste tracking numbers to each container and by maintaining records that trace the IDW back to the original sampling locations.

Rinsate shall be collected in DOT-compliant packages (49 Code of Federal Regulations [CFR] 172) (CFR, 1998d). Rinsate may be analyzed separately to determine final disposition. If rinsate is characterized as low-level waste on the basis of container-specific sampling or other methods, it may be solidified prior to NTSWAC certification activities.

\subsubsection{Hazardous Waste}

Suspected hazardous wastes will be managed in accordance with RCRA and State of Nevada hazardous waste management regulations, interpreted as follows. Suspected hazardous waste will be placed in DOT-compliant packages (49 CFR 172) (CFR, 1998d) which will be locked or fitted with TIDs. The IDW shall be containerized in a manner to comply with Subpart CC of 40 CFR 265 (CFR, 1998c) and the requirements of 40 CFR 265.172 (CFR, 1998c). Drums shall be handled and inspected in accordance with the requirements of 40 CFR 265.173 and 174, respectively (CFR, 1998c). No incompatible wastes are expected to be generated; however, if incompatible waste 
is encountered in the field, it will be managed in accordance with 40 CFR 265.177 (CFR, 1998c) (i.e., shall not be placed in the same container) and shall be separated so that in the event of a spill, leak, or release, incompatible wastes shall not contact one another.

Hazardous wastes shall be characterized in accordance with the requirements of 40 CFR 261 (CFR, 1998a). Characterization will be based on laboratory results and process knowledge. Packages containing IDW pending characterization will be marked with the words "Hazardous Waste Pending Analysis" until its regulatory status can be determined through interpretation and evaluation of laboratory results. Waste shall be traceable to its source and/or samples considered analogous to the waste (such as PPE associated with a sample). Traceability shall be maintained by assigning unique waste tracking numbers to each container and by maintaining records that trace the IDW back to the original samples. After receipt of analytical results, hazardous wastes (if identified) will be labeled and marked in accordance with the requirements of 40 CFR 262.32 (CFR, 1998b) and State of Nevada requirements, such as writing the EPA Waste Code number on the hazardous waste label.

Hazardous waste management methods to include the establishment of Satellite Accumulation Areas or a 90-day Hazardous Waste Accumulation Area (HWAA) will be employed to temporarily accumulate IDW pending characterization. These methods will be appropriate for the amount of waste being accumulated and in compliance with applicable State of Nevada and federal requirements.

If a HWAA is established, suspected hazardous waste will be accumulated at the HWAA for up to 90 days in accordance with 40 CFR 262.34 (CFR, 1998b). Prior to or on the ninetieth day of accumulation as specified in 40 CFR 262.34 (a) (CFR, 1998b), hazardous waste will be shipped by a licensed/permitted hazardous waste transporter to a permitted treatment, storage, and disposal facility. If hazardous waste must remain on-site for longer than 90 days due to unforeseen, temporary, and uncontrollable circumstances, a letter requesting an extension for up to 30 days will be sent to the NDEP in accordance with 40 CFR Part 262.11(b) (CFR, 1998b). A copy of the uniform hazardous waste manifest shall be provided to the State of Nevada. 


\subsubsection{Mixed Wastes}

Mixed waste, if generated, shall be managed in accordance with RCRA (40 CFR 262) (CFR, 1998b) and NAC 444 (NAC, 1998a). These regulations, as well as DOE requirements for radioactive waste are interpreted as follows. Where there is a conflict in regulations or requirements, the most stringent shall apply. For example, the 90-day accumulation time limit and weekly inspections per RCRA regulations will be applied to mixed waste even though it is not required for radioactive waste. Conversely, while RCRA does not require documented traceability, the waste acceptance program for LLW does; therefore, traceability shall be documented as described in Section 5.3.2.

In general, mixed waste shall be managed in the same manner as hazardous waste, with added mandatory radioactive waste management program requirements. Suspected mixed waste will be managed in accordance with applicable regulations and requirements and will be marked with the words "Hazardous Waste Pending Analysis" pending characterization and confirmation of its regulatory status. However, once the waste determination is made, or the RCRA 90-day time requirement draws to an end, mixed waste shall be transported via a permitted hazardous waste hauler to the NTS transuranic waste storage pad for storage pending treatment or disposal. Mixed waste with hazardous waste constituents below land disposal restrictions may be disposed of at the Area 5 Radioactive Waste Management Site.

Mixed waste not meeting land disposal restrictions will remain in Area 5 and require development of a treatment plan under the requirements of the Mutual Consent Agreement between DOE and the State of Nevada (NDEP, 1995)

\subsubsection{Hydrocarbon Waste}

Hydrocarbon waste, such as contaminated soil containing more than 100 milligrams per kilogram (mg/kg) TPH, will be properly containerized in bags or packages and will be transported to an appropriately permitted hydrocarbon waste management facility after the waste is fully characterized. Hydrocarbon waste which has come in contact with or has the potential to contact radiologically contaminated media is to be considered radiological waste and managed in accordance with the handling procedures for LLW. 


\subsection{Duration and Records Availability}

\subsection{Duration}

Following NDEP approval of this CAIP, the tentative schedule of activities (in calendar days) to occur after October 1, 1999:

- Day 0: Preparation for field work will begin.

- Day 55: Notify NDEP of upcoming field activities.

- Day 60: Field work, including field screening and sampling, will begin. Samples will be shipped to meet laboratory holding times.

- Day 70: Field work is complete.

- Day 185: The quality-assured laboratory analytical sample data will be available for review.

- $\quad$ The FFACO date for the CADD is currently October 31, 2000.

\subsection{Records Availability}

Historic information and documents referenced in this plan are retained in the DOE/NV project files in Las Vegas, Nevada, and can be obtained through written request to the DOE/NV Project Manager. This document is available in the DOE public reading rooms located in Las Vegas and Carson City, Nevada, or by contacting the DOE/NV Project Manager. The NDEP maintains the official Administrative Record for all activities conducted under the auspices of the FFACO. 


\subsection{References}

Adams, S.R. 1999. Memorandum to Juliana Herrington regarding the "Minimum Reporting Limits (MRLS) for Radiological Contaminants of Potential Concern for the Area 25 Engine Test Stand 1 Decontamination Pad, Corrective Action Unit (CAU) 252," 17 August. Las Vegas, NV.

Atlan-Tech. 1992. Environmental Monitoring Report for the Proposed Ward Valley California LLRW Facility. Rosewall, GA: Atlan-Tech Inc.

Bechtel Nevada. 1999. Radiation Survey Report for CAU252 ETS-1 Decon Pad. Ground survey conducted by Bechtel Nevada, 29 June. Las Vegas, NV.

Bernhardt, D.E., R.B. Evans, R.F. Grossman, F.N. Buck, and M.W.Carter. 1974. NRDS Nuclear Rocket Effluent Program 1959-1970, June. Prepared for U.S. Atomic Energy Commission. Las Vegas, NV: U.S. Environmental Protection Agency.

Bordelois, B. 1999. Oral communications with Betty Bordelois, the principal investigator for the Area 25 CAU 240 Vehicle Washdown Pads corrective action investigation, 20 July. Las Vegas, NV.

CFR, see Code of Federal Regulations.

Code of Federal Regulations. 1998a. 40 CFR Part 261, "Identification and Listing of Hazardous Wastes." Washington, DC: U.S. Government Printing Office.

Code of Federal Regulations. 1998b. 40 CFR Part 262, "Standards Applicable to Generators of Hazardous Waste.” Washington, DC: U.S. Government Printing Office.

Code of Federal Regulations. 1998c. 40 CFR Part 265, "Interim Status Standards for Owners and Operators of Hazardous Waste Treatment, Storage, and Disposal Facilities.” Washington, DC: U.S. Government Printing Office.

Code of Federal Regulations. 1998d. 49 CFR Part 172, "Hazardous Materials Table, Special Provisions, Hazardous Materials Communications, Emergency Response Information, and Training Requirements.” Washington, DC: U.S. Government Printing Office.

Desert Research Institute. 1988. CERCLA Preliminary Assessment of DOE's Nevada Operations Office, Nuclear Weapons Testing Area, Vol I. Las Vegas, NV.

DOE, see U.S. Department of Energy.

DOE/NV, see U.S. Department of Energy, Nevada Operations Office. 
DRI, see Desert Research Institute.

EPA, see U.S. Environmental Protection Agency.

FFACO, see Federal Facility Agreement and Consent Order.

Federal Facility Agreement and Consent Order. 1996 (as amended). Agreed to by the State of Nevada, the U.S. Department of Energy, and the U.S. Department of Defense.

Forsgren, F. (IT Corporation). 1998. Memorandum to R. Jackson (IT) entitled "CAU 252, CAS 25-07-04 Sampling Report," 03 March. Las Vegas, NV.

La Camera, R.J., G.L. Locke, and R.H. Munson. 1999. Selected Ground-Water Data for Yucca Mountain Region, Southern Nevada and Eastern California, Through December 1997, U.S. Geological Survey Open-File Report 98-628. Carson City, NV: U.S. Geological Survey.

McArthur, R.D., and F.L. Miller, Jr. 1989. Off-Site Radiation Exposure Review Project (ORERP), Phase II Soil Program, DOE/NV/10384--23. Las Vegas, NV: Desert Research Institute.

NAC, see Nevada Administrative Code.

NDEP, see Nevada Division of Environmental Protection.

Nevada Administrative Code. 1998a. NAC 444, "Sanitation." Carson City, NV: Nevada Division of Environmental Protection.

Nevada Administrative Code. 1998b. NAC 445A.2272, "Contamination of Soil: Establishment of Action Levels." Carson City, NV: Nevada Division of Environmental Protection.

Nevada Division of Environmental Protection. 1995. "Mutual Consent Agreement Between the State of Nevada and the Department of Energy for the Storage of Low-Level Land Disposal Restricted Mixed Waste." Transmittal from P. Liebendorfer (NDEP) to D. Elle (DOE/NV), 7 June. Carson City, NV.

Nevada Revised Statutes. 1998. 459.9973, 459.9975, and 459.9977, "Hazardous Materials." Carson City, NV: Nevada Division of Environmental Protection.

NRS, see Nevada Revised Statutes.

Pan Am, see Pan American World Airways, Inc.

Pan American World Airways, Inc. 1966. Detailed site plan engineering drawing for the "Mobile Radiation Check Point Site, Detail Site Plan ETS-1 (only)," AUX-PAA-0061. Mercury, NV: Archives and Records Center. 
Pan American World Airways, Inc. 1968. Six as-build engineering drawings for the "Mobile Radiation Checkpoint Site 'H' and 'K' Intersection," NRDS-SF-P29/V-1, C-1, C-2, M1, E1, E-2. Mercury, NV: Archives and Records Center.

SNPO, see Space Nuclear Propulsion Office.

Space Nuclear Propulsion Office. 1970. NRDS Master Plan 1969-1970, U.S. Government Memorandum dated 29 September from W.L. Walker distributing the Master Plan to several SNPO personnel. Las Vegas, NV.

U.S. Department of Energy. 1988. Site Characterization Plan, Yucca Mountain Site, Nevada, DOE/RW - 0199, Vols. I-IX. Las Vegas, NV.

U.S. Department of Energy, Nevada Operations Office. 1984. Nevada Test Site Area 25 Radiological Survey and Cleanup Project 1974-1983 (A Revised Final Report), Rev. 1, December, DOE/NV/10327--5. Las Vegas, NV.

U.S. Department of Energy, Nevada Operations Office. 1987. Nevada Test Site - Environmental Compliance Atlas, 15 June. Las Vegas, NV.

U.S. Department of Energy, Nevada Operations Office. 1994. Project Management Plan, Rev. 0. Las Vegas, NV.

U.S. Department of Energy, Nevada Operations Office. 1996a. Final Environmental Impact Statement for the Nevada Test Site and Off-Site Locations in the State of Nevada, DOE/EIS-243. Las Vegas, NV.

U.S. Department of Energy, Nevada Operations Office. 1996b. Industrial Sites Quality Assurance Project Plan, Nevada Test Site, Nevada, DOE/NV--372. Las Vegas, NV.

U.S. Department of Energy, Nevada Operations Office. 1996c. NV/YMP Radiological Control Manual, Rev. 2, DOE/NV/11718--079. Prepared by Bechtel Nevada. Las Vegas, NV.

U.S. Department of Energy, Nevada Operations Office. 1997. Nevada Test Site Waste Acceptance Criteria, NVO/NV--325, Rev. 1. Las Vegas, NV.

U.S. Department of Energy, Nevada Operations Office. 1998. Environmental Restoration Project Health and Safety Plan, Rev. 3. Las Vegas, NV.

U.S. Environmental Protection Agency. 1994. Guidance for the Data Quality Objectives Process, EPA QA/G-4. Washington, DC.

U.S. Environmental Protection Agency. 1998. Memo from S. J. Smucker regarding Region 9 Preliminary Remediation Goals (PRGs), 1 August. San Francisco, CA. 


\section{Appendix A}

\section{Data Quality Objectives Worksheets}




\section{A.1.0 Introduction}

\section{A.1.1 Problem Statement}

Potentially hazardous wastes were discharged to the CAU 252, CAS 25-07-04, Area 25 ETS-1 Decontamination Pad (ETS-1 Decontamination Pad) at the NTS. Effluent from vehicle decontamination at the ETS-1 Decontamination Pad could have been discharged to sump. Two pipes discharged to the sump (Figure A.1-1): one pipe from the decontamination pad drain and the other was a sewer pipe for a trailer. Soil near the northeast corner of the decontamination pad could also be contaminated. The decontamination pad slopes downward to the northeast and effluent from vehicle decontamination could have flowed northeast across the pad and ponded on the soil near the pad. Existing information about the nature and extent of contamination or about the decontamination activities that may have occurred at the site is insufficient to evaluate and select a preferred corrective action.

This CAU will be investigated based on DQOs developed by representatives of NDEP and DOE/NV. This investigation will determine if COPCs are present in soils at the site (i.e., the sump and the soil near the northeast corner of the decontamination pad). If COPCs are detected above PALs, the lateral and vertical extent of contamination will be delineated (e.g., step-out sampling may be conducted). Data adequate to close the site under NDEP, RCRA, and DOE requirements will be collected.

\section{A.1.2 DQO Kickoff Meeting}

Table A.1-1 lists the DQO participants present at the FFACO-required DQO Kickoff Meeting. These participants or additional pertinent personnel may be consulted as necessary for any subsequent meetings that may be required prior to submittal of the CAIP. The goal of the DQO process is to establish the quantity and quality of environmental data required to support corrective action decisions for the CAUs. The process ensures that the information collected will provide sufficient and reliable information to identify, evaluate, and technically defend the chosen corrective action. Unless otherwise required by the results of this DQO and stated in the CAIP, this investigation will adhere to the Industrial Sites QAPP (DOE/NV, 1996b). 


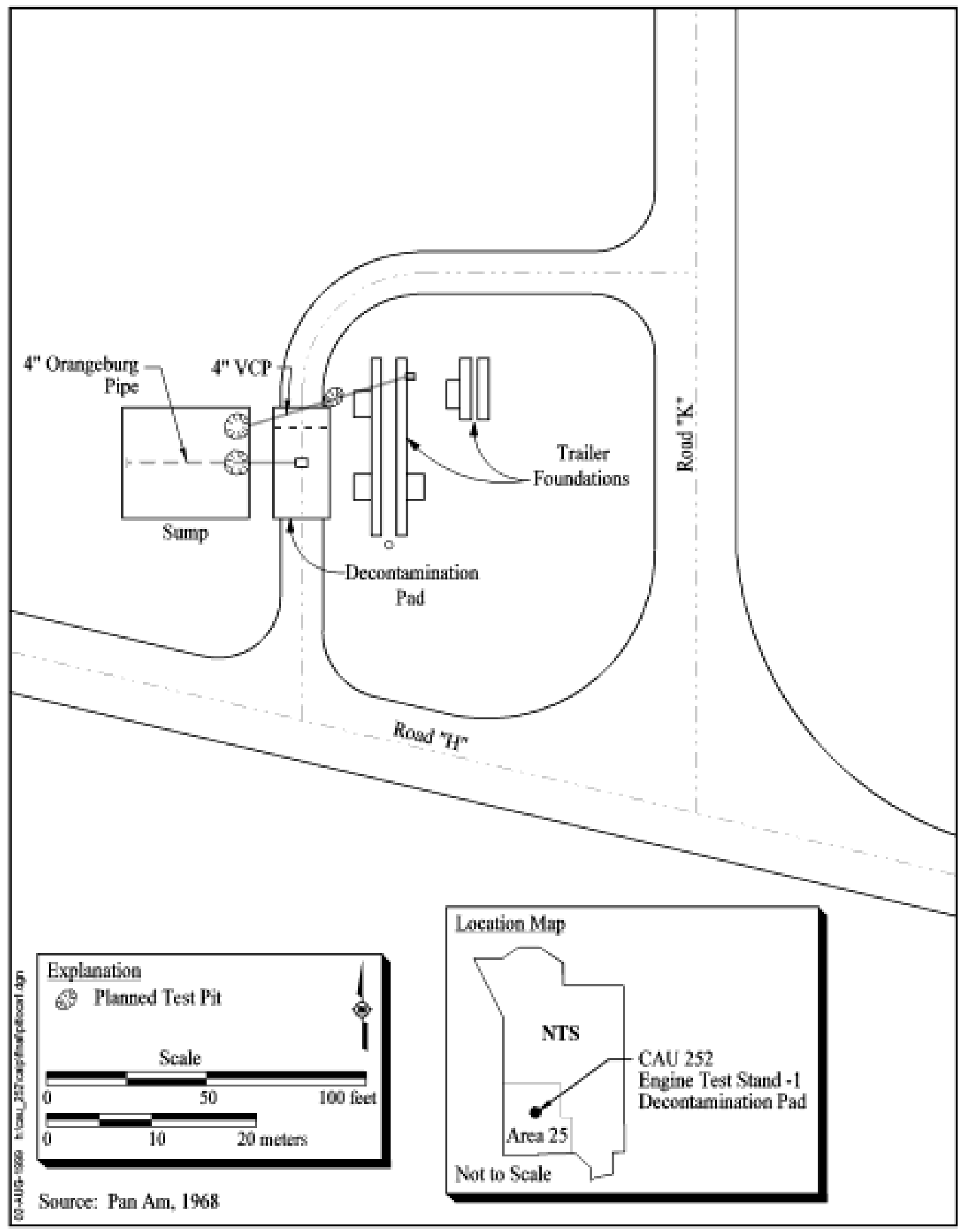

Figure A.1-1

CAU 252, Area 25 Engine Test Stand - 1 Decontamination Pad and Planned Test Pit Locations 
Table A.1-1

DQO Kickoff Meeting Participants

April 28, 1999

\begin{tabular}{|l|c|}
\hline \multicolumn{1}{|c|}{ Participant } & Affiliation \\
\hline \hline Mike McKinnon & NDEP \\
\hline Sabine Curtis & DOE/NV \\
\hline Matt Klainer & IT \\
\hline Syl Hersh & IT \\
\hline Juliana Herrington & SAIC \\
\hline Lydia Coleman & SAIC \\
\hline Carrye Putz & IT \\
\hline Shannon Parsons - DePry & BN \\
\hline Robert Curiale & IT \\
\hline Jeff Johnson & IT \\
\hline Steve Adams & IT \\
\hline Milinka Watson-Garrett & BN \\
\hline Don Cox & SAIC \\
\hline Mary Todd & MACTEC \\
\hline Jeanne Wightman & IT \\
\hline
\end{tabular}

BN - Bechtel Nevada

DOE/NV - U.S. Department of Energy, Nevada Operations Office

IT - IT Corporation

MACTEC - Management Analysis Company Technologies

NDEP - Nevada Division of Environmental Protection

SAIC - Science Applications International Corporation 


\section{A.2.0 Conceptual Model}

The NRDS in Area 25 of the Nevada Test Site was operational primarily between 1958 and 1973 (Bernhardt et al., 1974; DOE/NV, 1984). The NRDS complex consisted of several buildings, test facilities, and support systems used for the development and testing of nuclear rocket engines. The NRDS complex included the ETS-1 facility which was constructed in 1966 for use as a test stand for testing nuclear rockets (SNPO, 1970). The ETS-1 Decontamination Pad was constructed in 1968 for use as a mobile radiation checkpoint and for vehicle decontamination. The site is located in Area 25 at the intersection of Road H and Road K (Pan Am, 1966; Pan Am, 1968). The conceptual site model for the ETS-1 Decontamination Pad is provided in Table A.2-1. 
Table A.2-1

CAU 252 Conceptual Model Element Descriptions (Page 1 of 2)

\begin{tabular}{|c|c|c|}
\hline $\begin{array}{c}\text { Conceptual Model } \\
\text { Element }\end{array}$ & Description & Source \\
\hline \multirow{3}{*}{$\begin{array}{l}\text { ETS-1 } \\
\text { Decontamination Pad } \\
(\text { CAS 25-07-04) }\end{array}$} & $\begin{array}{l}\text { The ETS-1 Decontamination Pad is located at the northwest } \\
\text { corner of the intersection of Road H and Road K in Area } 25 \text { of } \\
\text { the NTS. }\end{array}$ & $\begin{array}{l}\text { Engineering drawings } \\
\text { (Pan Am, 1966; } \\
\quad \text { Pan Am, 1968) }\end{array}$ \\
\hline & $\begin{array}{l}\text { The CAU } 252 \text { site includes: } \\
\text { - A concrete decontamination pad that measures about } \\
35 \mathrm{ft} \text { by } 15 \mathrm{ft} \text { with a grated drain ( } 18 \mathrm{in} \text {. by } 6 \text { in.). There } \\
\text { are two light poles on either side of the pad. The } \\
\text { decontamination pad slopes to the northeast. } \\
\text { - A gravel-filled sump measures } 31 \mathrm{ft} \text { by } 35 \mathrm{ft} \text {. The } \\
\text { surface of the sump is below the general topography of } \\
\text { the nearby area. } \\
\text { Concrete trailer pads: Two parallel concrete pads that } \\
\text { measure } 3 \mathrm{ft} \text { by } 55 \mathrm{ft} \text { and two parallel concrete pads that } \\
\text { measure } 3 \mathrm{ft} \text { by } 18 \mathrm{ft} \text {. Two small concrete pads for the } \\
\text { trailer tongues. } \\
\text { Several utility boxes. } \\
\text { Dimensions for the entire CAU } 252 \text { site are } 115 \mathrm{ft} \text { by } \\
60 \mathrm{ft} \text {. }\end{array}$ & $\begin{array}{l}\text { Engineering drawings } \\
\text { (Pan Am, 1966; } \\
\text { Pan Am, 1968) } \\
\text { Site observation } \\
\text { (ITLV, 1994) }\end{array}$ \\
\hline & $\begin{array}{l}\text { The ETS- } 1 \text { test stand constructed in } 1966 \text { is part of the } \\
\text { NRDS facility. The CAU } 252 \text { ETS- } 1 \text { Decontamination Pad } \\
\text { and mobile radiation check point was built in } 1968 \text {. The } \\
\text { NRDS complex ceased primary operations in } 1973 \text {. }\end{array}$ & $\begin{array}{l}\text { Process knowledge } \\
\text { (Bernhardt et al., 1974; } \\
\text { DOE/NV, 1984; } \\
\text { Pan Am, 1966; } \\
\text { Pan Am, 1968) }\end{array}$ \\
\hline \multirow[b]{3}{*}{ Evidence for COPCs } & $\begin{array}{l}\text { The CAU } 252 \text { site was designed for use as a mobile radiation } \\
\text { check point and for vehicle decontamination. If COPCs are } \\
\text { present, they would most likely be associated with } \\
\text { radiological decontamination processes. }\end{array}$ & $\begin{array}{l}\text { Engineering drawings } \\
\text { (Pan Am, 1966; } \\
\quad \text { Pan Am, 1968) }\end{array}$ \\
\hline & There are no visible stains or odors at the site. & $\begin{array}{l}\text { Site observation } \\
\text { (ITLV, 1994; } \\
\text { ITLV, 1997) }\end{array}$ \\
\hline & $\begin{array}{l}\text { A preliminary sample (ERS00044) was collected on } \\
\text { August 15, 1997. The sample was collected from the soil } \\
\text { near the northeast corner of the decontamination pad. The } \\
\text { sample was analyzed for VOCs, SVOCs, TPH-diesel range } \\
\text { organics, RCRA metals, PCBs, gross alpha/beta, and } \\
\text { gamma emitters. The results of these analyses did not } \\
\text { indicate any COPCs above EPA Region IX Industrial Soil } \\
\text { PRGs. These data were used to assist in developing the } \\
\text { COPC list for the CAU } 252 \text { investigation. }\end{array}$ & $\begin{array}{l}\text { Process knowledge } \\
\text { (Forsgren, 1998) }\end{array}$ \\
\hline
\end{tabular}


Table A.2-1

CAU 252 Conceptual Model Element Descriptions (Page 2 of 2)

\begin{tabular}{|c|c|c|}
\hline $\begin{array}{l}\text { Conceptual Model } \\
\text { Element }\end{array}$ & Description & Source \\
\hline \multirow{4}{*}{ Extent of COPCs } & $\begin{array}{l}\text { If COPCs were released at the site, assume relatively low } \\
\text { contaminant concentrations. Process knowledge from other } \\
\text { decontamination pads within Area } 25 \text { also show little to no } \\
\text { contamination (CAU } 240 \text { Area } 25 \text { Vehicle Washdown Pads). }\end{array}$ & $\begin{array}{l}\text { Process knowledge } \\
\text { (Pan Am, 1966; } \\
\text { Pan Am, 1968) }\end{array}$ \\
\hline & $\begin{array}{l}\text { The extent of lateral contamination, if present, is not } \\
\text { expected beyond the CAU } 252 \text { area. Any COPC releases at } \\
\text { the site are due to decontamination processes and not from } \\
\text { deliberate waste disposal. }\end{array}$ & $\begin{array}{l}\text { Process knowledge } \\
\qquad(\mathrm{CAU} 240)\end{array}$ \\
\hline & $\begin{array}{l}\text { COPCs are of relatively minor vertical extent. The site, if } \\
\text { used, would have been used intermittently. There is no } \\
\text { evidence the sump had a sufficient and/or sustained } \\
\text { hydraulic head to act as a significant driving force to mobilize } \\
\text { contaminants to large depths. Annual precipitation, soil type, } \\
\text { and the arid environment are not adequate to support } \\
\text { appreciable downward contaminant movement. }\end{array}$ & $\begin{array}{l}\text { Process Knowledge } \\
\text { (NTS and Yucca } \\
\text { Mountain climate data, } \\
\text { various reports; } \\
\text { CAU } 240 \text { project) }\end{array}$ \\
\hline & $\begin{array}{l}\text { The CAU } 252 \text { site was designed for use as mobile radiation } \\
\text { checkpoint and for vehicle decontamination. Currently the } \\
\text { site is abandoned. }\end{array}$ & $\begin{array}{l}\text { Process knowledge } \\
\text { (Bernhardt et al., 1974; } \\
\text { DOE/NV, 1984; } \\
\text { Pan Am, 1966; } \\
\text { Pan Am, 1968) }\end{array}$ \\
\hline Future use of the site & $\begin{array}{l}\text { Future site use is restricted per the NTS Environmental } \\
\text { Impact Statement. }\end{array}$ & $\begin{array}{l}\text { Environmental Impact } \\
\text { Statement } \\
\text { (DOE/NV, 1996a) }\end{array}$ \\
\hline Potential receptors & $\begin{array}{l}\text { Potential for exposure is mainly to field personnel and } \\
\text { workers performing investigations at this site. }\end{array}$ & $\begin{array}{l}\text { NTS excavation } \\
\text { activities }\end{array}$ \\
\hline
\end{tabular}




\section{A.3.0 Potential Contaminants}

The gravel sump for the ETS-1 Decontamination Pad was designed to receive decontamination effluent from the decontamination pad and sewage from the larger trailer pad. The decontamination pad slopes downward to the northeast. If the decontamination pad was used, the effluent would have most likely drained toward the northeast corner of the pad and not necessarily down the drain. The COPCs for CAU 252 include the following:

- Radiological emitters associated with decontamination activities are the indicator parameter or primary COPC. Radiological emitters will be evaluated through field surveys and laboratory analyses.

- Other COPCs for this site include total VOCs, total SVOCs, TPH-diesel, RCRA metals, total pesticides, and PCBs. These COPCs will be evaluated through field screening and/or laboratory analyses for one or more of the following reasons:

- Potential for being associated with solvents and/or vehicles potentially decontaminated used during the decontamination process

- Evaluated for as a precautionary measure because of operations associated with a nuclear facility

- Additional samples may also be collected for waste management purposes.

Section 3.0 of the CAIP provides additional information on the COPCs for CAU 252, including PALs and QA/QC requirements (Table A.3-1). The precision, accuracy, and practical quantitation limits are contained in Appendix C. 
Table A.3-1

CAU 252 ETS-1 Decontamination Pad Contaminants of Potential Concern

\begin{tabular}{|c|c|c|c|c|c|c|c|}
\hline Analyte & Comments & $\begin{array}{c}\text { Field } \\
\text { Screening } \\
\text { Method }\end{array}$ & $\begin{array}{c}\text { Field } \\
\text { Screening } \\
\text { Level }\end{array}$ & $\begin{array}{c}\text { Conduct } \\
\text { Analytical? }\end{array}$ & $\begin{array}{c}\text { Analytical } \\
\text { Method }\end{array}$ & $\begin{array}{l}\text { Preliminary } \\
\text { Action Level }\end{array}$ & Source $^{c}$ \\
\hline $\begin{array}{c}\text { Volatile Organic } \\
\text { Compounds }\end{array}$ & Unlikely & Headspace & $\begin{array}{c}20 \text { ppm or } 2.5 X \\
\text { background (use } \\
\text { greater value) }\end{array}$ & Yes $^{*}$ & $8260 B^{a}$ & $\mathrm{PRGs}^{\mathrm{b}}$ & NAC $445 \mathrm{~A}$ \\
\hline $\begin{array}{l}\text { Semivolatile } \\
\text { Organic } \\
\text { Compounds }\end{array}$ & Unlikely & NA & NA & Yes* & $8270 c^{a}$ & $\mathrm{PRGs}^{\mathrm{b}}$ & NAC $445 \mathrm{~A}$ \\
\hline $\begin{array}{l}\text { Total Petroleum } \\
\text { Hydrocarbons } \\
\text { (diesel) }\end{array}$ & Unlikely & NA & NA & Yes* & 8015B modified ${ }^{\mathrm{a}}$ & $100 \mathrm{mg} / \mathrm{kg}^{\mathrm{c}}$ & NAC $445 \mathrm{~A}$ \\
\hline $\begin{array}{l}\text { Total RCRA } \\
\text { Metals }\end{array}$ & Unlikely & NA & NA & Yes $^{*}$ & $\begin{array}{l}6010 B / 7470 A^{a} \\
6010 B / 7471 A^{a}\end{array}$ & $\mathrm{PRG}^{\mathrm{b}}$ & NAC $445 \mathrm{~A}$ \\
\hline Total Pesticides & Unlikely & NA & NA & Yes $^{*}$ & $8081 A^{c}$ & $\mathrm{PRGs}^{\mathrm{b}}$ & NAC 445A \\
\hline $\begin{array}{l}\text { Polychlorinated } \\
\text { Biphenyls }\end{array}$ & $\begin{array}{l}\text { Unlikely, } \\
\text { detected in a } \\
\text { very low } \\
\text { concentration in } \\
\text { preliminary } \\
\text { sample }\end{array}$ & NA & NA & Yes* & $8082^{c}$ & $P R G s^{b}$ & NAC $445 \mathrm{~A}$ \\
\hline Radionuclides & $\begin{array}{l}\text { Potential for } \\
\text { radionuclides } \\
\text { because the site } \\
\text { was designed for } \\
\text { use as a mobile } \\
\text { radiological } \\
\text { check point and } \\
\text { for vehicle } \\
\text { decontamination }\end{array}$ & $\begin{array}{c}\text { Electra } \\
\text { alpha/beta } \\
\text { scintillator, } \\
\text { sodium iodide } \\
\text { detector, and/or } \\
\text { intrinsic } \\
\text { germanium } \\
\text { detector (or } \\
\text { equivalent) }\end{array}$ & $\begin{array}{l}\text { Mean background } \\
\text { activity plus } 2 \\
\text { times standard } \\
\text { deviations of } \\
\text { background } \\
\text { readings }\end{array}$ & Yes* & $\begin{array}{c}\text { Gamma } \\
\text { Spectroscopy }^{d}\end{array}$ & $\begin{array}{l}\text { Isotopic-specific } \\
\text { value based on } \\
\text { maximum } \\
\text { isotopic } \\
\text { background data }\end{array}$ & NA \\
\hline
\end{tabular}

${ }^{a}$ Test Methods for Evaluating Solid Waste, Third Edition, Parts 1-4, SW-846 (EPA, 1996)

${ }^{\mathrm{b}}$ Region IX Industrial Soil Preliminary Remediation Goals (PRGs) (EPA, 1998)

${ }^{\mathrm{C}}$ Nevada Administrative Code (NAC, 1998)

dSee Table C.1-1 for specific analyses

$\mathrm{NA}=$ Not applicable for this project

${ }^{*}$ As specified in text Section 3.0 of the CAIP 


\section{A.3.1 Decisions}

The primary decision to be made from the investigation is whether the sump or soil near the northeast corner of the pad have been adversely impacted by decontamination activities. Decisions to be resolved by the investigation include the following:

- Determine the presence or absence of COPCs.

- If COPCs are present, determine the type and concentrations of COPCs.

- If COPCs are present, determine whether the COPC concentrations exceed the PALs.

- Determine the nature and extent of contamination (or absence of contamination) with enough certainty to develop and evaluate a range of potential corrective actions, including closure in place and clean closure.

\section{A.3.2 Inputs and Strategy}

Inputs to the decisions are those elements of information used to support the decisions in addressing the identified problem. A list of information inputs, existing data, identified data gaps, and brief strategies are discussed in Table A.3-2. A more detailed discussion of investigation strategies is found in Section A.4.0. 
Table A.3-2

CAU 252 Decisions, Inputs, and General Strategies

(Page 1 of 3 )

\begin{tabular}{|c|c|c|c|c|}
\hline Decision & Input & Existing Data & Data Gap & Strategy \\
\hline \multirow{3}{*}{$\begin{array}{l}\text { Are COPCs present } \\
\text { above PALs at site? }\end{array}$} & $\begin{array}{l}\text { Potential contaminant } \\
\text { identification }\end{array}$ & $\begin{array}{l}\text { Process knowledge indicates } \\
\text { the site was designed for use } \\
\text { as a mobile radiation check } \\
\text { point and for vehicle } \\
\text { decontamination. }\end{array}$ & Exact COPCs & $\begin{array}{l}\text { Conduct utility, video, and/or } \\
\text { geophysical surveys, as necessary. } \\
\text { Conduct radiological survey. Collect } \\
\text { soil samples and analyze for } \\
\text { COPCs. }\end{array}$ \\
\hline & $\begin{array}{l}\text { Potential contaminant } \\
\text { concentration }\end{array}$ & $\begin{array}{l}\text { A preliminary sample } \\
\text { (ERS00044) was collected on } \\
\text { August 15, 1997. The sample } \\
\text { was analyzed for VOCs, } \\
\text { SVOCs, TPH-diesel, RCRA } \\
\text { metals, PCBs, gross } \\
\text { alpha/beta, and gamma } \\
\text { emitters. The results of these } \\
\text { analyses did not indicate any } \\
\text { COPCs above EPA Region IX } \\
\text { Industrial Soil PRGs. }\end{array}$ & $\begin{array}{l}\text { Identify COPCs and } \\
\text { concentrations }\end{array}$ & $\begin{array}{l}\text { Collect soil samples with a backhoe } \\
\text { for field screening and laboratory } \\
\text { analyses. Direct-push methods may } \\
\text { be used as necessary for sample } \\
\text { collection. Field survey for } \\
\text { radiological emitters. The planned } \\
\text { soil sample locations are biased to } \\
\text { worst-case areas (i.e., sump and soil } \\
\text { near the northeast corner of the } \\
\text { decontamination pad); compare } \\
\text { results to FSLs and/or to PALs. } \\
\text { Conduct additional (step-out) } \\
\text { sampling, as necessary. }\end{array}$ \\
\hline & $\begin{array}{l}\text { Potential contaminant } \\
\text { distribution }\end{array}$ & $\begin{array}{l}\text { Location of the ETS-1 } \\
\text { Decontamination Pad. The } \\
\text { vertical and lateral extent of } \\
\text { COPCs is assumed to be } \\
\text { limited to the sump and in the } \\
\text { soil near the northeast corner } \\
\text { of the decontamination pad. } \\
\text { There is a lack of driving force } \\
\text { due to arid environment and } \\
\text { the COPCs are relatively } \\
\text { immobile. }\end{array}$ & $\begin{array}{l}\text { Identify vertical and lateral } \\
\text { extent of COPCs }\end{array}$ & $\begin{array}{l}\text { See strategy (above) for determining } \\
\text { if COPCs are present above PALs at } \\
\text { site. }\end{array}$ \\
\hline
\end{tabular}


Table A.3-2

CAU 252 Decisions, Inputs, and General Strategies

(Page 2 of 3 )

\begin{tabular}{|c|c|c|c|c|}
\hline Decision & Input & Existing Data & Data Gap & Strategy \\
\hline \multirow{6}{*}{$\begin{array}{l}\text { Are potential } \\
\text { contaminants } \\
\text { migrating? }\end{array}$} & $\begin{array}{l}\text { Relative mobility of potential } \\
\text { contaminant }\end{array}$ & $\begin{array}{l}\text { Process knowledge from } \\
\text { similar decontamination pads } \\
\text { (CAU } 240 \text { Area } 25 \text { Vehicle } \\
\text { Washdown Pads) indicate } \\
\text { COPCs primarily occur within } \\
3 \mathrm{ft} \text { to } 5 \mathrm{ft} \text { bgs. }\end{array}$ & $\begin{array}{l}\text { Identify COPCs and } \\
\text { concentrations }\end{array}$ & $\begin{array}{l}\text { See strategy (above) for determining } \\
\text { if COPCs are present above PALs at } \\
\text { site. }\end{array}$ \\
\hline & $\begin{array}{l}\text { Potential contaminant } \\
\text { distribution }\end{array}$ & $\begin{array}{l}\text { Limited by COPC type, } \\
\text { surficial geology, operational } \\
\text { practices, and meteorological } \\
\text { characteristics }\end{array}$ & $\begin{array}{l}\text { Identify vertical and lateral } \\
\text { extent of COPCs }\end{array}$ & $\begin{array}{l}\text { See strategy (above) for determining } \\
\text { if COPCs are present above PALs at } \\
\text { site. }\end{array}$ \\
\hline & Meteorologic data & $\begin{array}{l}\text { NTS and Yucca Mountain } \\
\text { Project data on annual } \\
\text { precipitation, evaporation, } \\
\text { evapotranspiration, and } \\
\text { weather. }\end{array}$ & Sufficient information exists. & $\begin{array}{l}\text { No site-specific meteorological data } \\
\text { will be collected. General weather } \\
\text { conditions (e.g., sunny, breezy, cool, } \\
\text { hot) are noted on daily field notes. }\end{array}$ \\
\hline & Geologic/hydrologic data & $\begin{array}{l}\text { NTS and Yucca Mountain } \\
\text { Project data describing } \\
\text { general geologic and/or } \\
\text { hydrologic characteristics of } \\
\text { the NTS and surrounding } \\
\text { area. }\end{array}$ & Sufficient information exists. & $\begin{array}{l}\text { No specific geologic or hydrologic } \\
\text { sample data will be collected for this } \\
\text { site. Sampling for this investigation } \\
\text { will not exceed } 12 \mathrm{ft} \text { bgs. General } \\
\text { soil characteristics will be noted on } \\
\text { sample collection log. }\end{array}$ \\
\hline & Biological degradation factors & Not applicable & None anticipated & $\begin{array}{l}\text { There are no plans to collect } \\
\text { microbial samples; however, if } \\
\text { laboratory analytical results indicate } \\
\text { higher than expected concentrations } \\
\text { of TPH, then samples may be } \\
\text { collected. }\end{array}$ \\
\hline & Radiological data & $\begin{array}{l}\text { Man-made radionuclides may } \\
\text { be present at this site. }\end{array}$ & $\begin{array}{l}\text { Conduct ground survey prior } \\
\text { the field investigation. } \\
\text { Conduct sample surveys } \\
\text { during the field investigation. }\end{array}$ & $\begin{array}{l}\text { Establish background; field survey } \\
\text { for alpha/beta/gamma radiation; and } \\
\text { collect samples for gamma } \\
\text { spectroscopy. }\end{array}$ \\
\hline
\end{tabular}


Table A.3-2

CAU 252 Decisions, Inputs, and General Strategies

(Page 3 of 3 )

\begin{tabular}{|c|c|c|c|c|}
\hline Decision & Input & Existing Data & Data Gap & Strategy \\
\hline \multirow{3}{*}{$\begin{array}{l}\text { Data sufficient to } \\
\text { support closure } \\
\text { options? }\end{array}$} & No further action & $\begin{array}{l}\text { The ETS-1 Decontamination } \\
\text { Pad site was designed for use } \\
\text { as a mobile radiation } \\
\text { checkpoint and for vehicle } \\
\text { decontamination. }\end{array}$ & $\begin{array}{l}\text { Presence, concentration, and } \\
\text { extent of COPCs }\end{array}$ & $\begin{array}{l}\text { Insufficient evidence to proceed } \\
\text { without investigation. Collect field } \\
\text { and laboratory samples; compare } \\
\text { results to PALs. If no COPCs above } \\
\text { PALs, prepare CADD/CR. }\end{array}$ \\
\hline & $\begin{array}{l}\text { Closure in place by } \\
\text { administrative controls }\end{array}$ & $\begin{array}{l}\text { Potential for COPCs; assume } \\
\text { industrial soil PRGs per NAC } \\
445 \mathrm{~A} \text { (NAC, 1998); assume } \\
100 \mathrm{mg} / \mathrm{kg} \text { for TPH per NAC } \\
445 \mathrm{~A} \text {; assume use } \\
\text { restrictions with signs and } \\
\text { fencing as needed. }\end{array}$ & $\begin{array}{l}\text { Presence of regulated } \\
\text { COPCs; concentrations above } \\
\text { PALs; groundwater protection }\end{array}$ & $\begin{array}{l}\text { Collect field and laboratory samples; } \\
\text { compare results to PALs. If no } \\
\text { COPCs above PALs, prepare } \\
\text { CADD/CR; otherwise prepare } \\
\text { CADD. }\end{array}$ \\
\hline & $\begin{array}{l}\text { Clean closure by contaminant } \\
\text { removal }\end{array}$ & $\begin{array}{l}\text { Potential for COPCs; assume } \\
\text { industrial soil PRGs per NAC } \\
445 \mathrm{~A} \text {; assume } 100 \mathrm{mg} / \mathrm{kg} \text { for } \\
\text { TPH per NAC } 445 \mathrm{~A} \text {. }\end{array}$ & $\begin{array}{l}\text { Presence, concentration, and } \\
\text { extent of COPCs; volume of } \\
\text { contaminated material above } \\
\text { PALs }\end{array}$ & $\begin{array}{l}\text { Collect field and laboratory samples; } \\
\text { compare results to PALs. If no } \\
\text { COPCs above PALs, prepare } \\
\text { CADD/CR; otherwise prepare } \\
\text { CADD. }\end{array}$ \\
\hline
\end{tabular}

PRGs - Preliminary Remediation Goal(s) 


\section{A.4.0 Investigation Strategy}

The investigation strategy for the ETS-1 Decontamination Pad site includes the following activities:

- Conduct a utility survey prior to excavation activities.

- Determine radiological field-screening levels using an Electra alpha/beta scintillator, a sodium iodide detector, or intrinsic germanium detector (or equivalent) by taking 20 background sample readings and calculating the mean plus two standard deviations.

- A backhoe will be used to remove the gravel-fill from test pit locations in the sump prior to sampling soil in the sump.

- Excavate three test pits with a backhoe. Samples will be collected at approximately 2-ft intervals to a maximum depth of about $12 \mathrm{ft} \mathrm{bgs} \mathrm{(or} \mathrm{the} \mathrm{maximum} \mathrm{reach} \mathrm{of} \mathrm{the} \mathrm{backhoe).} \mathrm{The}$ planned locations for the test pits are as follows:

- In the sump where the decontamination pad drain pipe discharged

- In the sump where the sewer pipe discharged

- The soil near the northeast corner of the decontamination pad where runoff from decontamination effluent would have most likely ponded

- Collect soil samples for laboratory analysis as follows:

- Soil samples will be collected at the gravel-soil interface in each of the sump test pits. Soil samples will be collected from each test pit, at approximately 2-ft depth intervals until a sample has been collected below FSLs or to the maximum reach of the backhoe (about $12 \mathrm{ft}$ bgs or about $6 \mathrm{ft}$ below the gravel/soil interface). At a minimum two depth intervals will be sampled.

- At the test pit near the northeast corner of the decontamination pad soil sampling at this location will begin at ground surface and continue at approximately 2 -ft depth intervals until a sample has been collected below FSLs or to the maximum reach of the backhoe (about $12 \mathrm{ft}$ bgs). At a minimum two depth intervals will be sampled.

- If field-screening results exceed field-screening levels at $12 \mathrm{ft}$ bgs (or the maximum reach of the backhoe), then sampling will stop and the investigation will be rescoped.

- If COPCs are not detected above PALs, prepare CADD/CR.

- Field screen for VOCs using the headspace technique with a photoionization detector. 
- Field survey for radioactivity using an Electra alpha/beta scintillator, a sodium iodide detector, or intrinsic germanium detector (or equivalent).

- Conduct a geophysical survey to locate the piping, as necessary.

- Conduct a video survey to locate breaches in piping, as necessary.

- Conduct laboratory analysis for gamma emitters, total VOCs, total SVOCs, TPH-diesel, RCRA metals, total pesticides, and PCBs.

- Collect and submit quality control samples as prescribed in the QAPP.

- Collect additional samples should the following occur:

- Field-screening levels or preliminary actions levels are exceeded and contamination needs to be further delineated.

- Data are insufficient for a corrective action decision document evaluation.

- Needed for waste management purposes.

- Site Supervisor determines it to be necessary. 


\section{A.5.0 Decision Rules}

The following decision rules (Table A.5-1) are applicable to the ETS-1 Decontamination Pad site and will be used to guide the investigation and subsequent data evaluation.

- If, in the course of the investigation, either of the following occur, the investigation will be halted and rescoped as necessary:

- The conceptual model fails to such a degree that rescoping is required.

- Sufficient data are collected to support evaluation of corrective actions.

- If analytical results are not adequate for preparation of a CADD and/or for waste management purposes, additional (step-out) samples may be collected and submitted for analyses at the discretion of the Site Supervisor.

- If COPCs extend beyond $12 \mathrm{ft}$ bgs (or maximum reach of the backhoe), the investigation will be stopped and rescoped.

- If laboratory results indicate the presence of COPCs above PALs, a CADD will be prepared.

- If no COPCs are identified above PALs, a CADD/CR will be prepared according to the outline agreed upon by NDEP and DOE/NV. 
Table A.5-1

CAU 252 Site-Specific Decision Points and Rules

\begin{tabular}{|c|c|c|c|}
\hline $\begin{array}{l}\text { Investigation } \\
\text { Activity }\end{array}$ & Decision Point & $\begin{array}{l}\text { Decision } \\
\text { Result }\end{array}$ & Decision Rule \\
\hline \multirow{7}{*}{$\begin{array}{l}\text { Excavation and } \\
\text { Soil Sample } \\
\text { Collection in } \\
\text { Sump }\end{array}$} & \multirow{3}{*}{$\begin{array}{l}\text { Can the piping discharge } \\
\text { points be located? }\end{array}$} & Yes & Proceed with sampling and investigation. \\
\hline & & $\begin{array}{l}\text { Yes, but in a } \\
\text { different } \\
\text { location }\end{array}$ & $\begin{array}{l}\text { Adjust sampling location and proceed with } \\
\text { investigation. }\end{array}$ \\
\hline & & No & $\begin{array}{l}\text { Piping may have been removed; proceed with } \\
\text { sampling and investigation; evaluate field data to } \\
\text { determine if sampling location is correct; notify } \\
\text { appropriate personnel; adjust sampling location; } \\
\text { conduct a geophysical or video survey to locate } \\
\text { piping discharge points as necessary. }\end{array}$ \\
\hline & \multirow[t]{2}{*}{$\begin{array}{l}\text { Are radiological survey } \\
\text { results above FSLs } \\
\text { Table A.3-1? }\end{array}$} & Yes & $\begin{array}{l}\text { All soil samples collected at the test pits will be } \\
\text { submitted to the laboratory analysis for gamma } \\
\text { emitters, total VOCs, total SVOCs, TPH-diesel, } \\
\text { RCRA metals, total pesticides, and PCBs. } \\
\text { Any additional (step-out) samples collected will be } \\
\text { submitted for laboratory analyses as specified by the } \\
\text { Site Supervisor. }\end{array}$ \\
\hline & & No & $\begin{array}{l}\text { All soil samples collected at the test pits will be } \\
\text { submitted to the laboratory analysis for gamma } \\
\text { emitters, total VOCs, total SVOCs, TPH-diesel, } \\
\text { RCRA metals, total pesticides, and PCBs. }\end{array}$ \\
\hline & \multirow[t]{2}{*}{$\begin{array}{l}\text { Are VOC results above } \\
\text { FSLs } \\
\text { Table A.3-1? }\end{array}$} & Yes & $\begin{array}{l}\text { All soil samples collected at the test pits will be } \\
\text { submitted to the laboratory analysis for gamma } \\
\text { emitters, total VOCs, total SVOCs, TPH-diesel, } \\
\text { RCRA metals, total pesticides, and PCBs. } \\
\text { Any additional (step-out) samples collected will be } \\
\text { submitted for laboratory analyses as specified by the } \\
\text { Site Supervisor. }\end{array}$ \\
\hline & & No & $\begin{array}{l}\text { All soil samples collected at the test pits will be } \\
\text { submitted to the laboratory analysis for gamma } \\
\text { emitters, total VOCs, total SVOCs, TPH-diesel, } \\
\text { RCRA metals, total pesticides, and PCBs. }\end{array}$ \\
\hline \multirow{2}{*}{$\begin{array}{l}\text { Video Survey } \\
\text { and Soil } \\
\text { Sampling }\end{array}$} & \multirow{2}{*}{$\begin{array}{l}\text { Can discharge points of } \\
\text { piping be found with } \\
\text { backhoe or process } \\
\text { knowledge? }\end{array}$} & Yes & Proceed with investigation and sampling. \\
\hline & & No & $\begin{array}{l}\text { Conduct video survey to locate discharge points for } \\
\text { piping, as necessary. }\end{array}$ \\
\hline \multirow{2}{*}{$\begin{array}{l}\text { Geophysical } \\
\text { Survey and Soil } \\
\text { Sampling }\end{array}$} & \multirow{2}{*}{$\begin{array}{l}\text { Can discharge points of } \\
\text { piping be found with } \\
\text { backhoe or process } \\
\text { knowledge? }\end{array}$} & Yes & Proceed with investigation and sampling. \\
\hline & & No & $\begin{array}{l}\text { Conduct geophysical survey to locate piping, as } \\
\text { necessary. }\end{array}$ \\
\hline
\end{tabular}




\section{A.6.0 Decision Error}

Biased sampling locations will be selected for soil sampling at the CAU 252 ETS-1 Decontamination Pad site as identified in Sections A.3.0, A.4.0, and A.5.0. The sampling strategy targets the worst-case contamination by directly sampling areas where contamination will most likely be present. Sampling areas include the sump and the soil near the northeast corner of the decontamination pad. The decontamination pad slopes downward to the northeast and effluent from decontamination activities could have runoff the pad and ponded in this location. Additional soil samples will be collected if laboratory results indicate significant contamination is present and the contamination needs to be further delineated. This sampling strategy will yield the highest confidence that the extent of contamination, if present, has been adequately bounded. Samples will be field screened and submitted to a laboratory for analyses using the rationale in Section A.3.0 and Section A.4.0. 


\section{A.7.0 References}

Bernhardt, D.E., R.B. Evans, R.F. Grossman, F.N. Buck, and M.W.Carter. 1974. NRDS Nuclear Rocket Effluent Program 1959-1970, June. Prepared for U.S. Atomic Energy Commission. Las Vegas, NV: U.S. Environmental Protection Agency.

CFR, see Code of Federal Regulations.

Code of Federal Regulations. 1998. 40 CFR Part 261, "Identification and Listing of Hazardous Waste." Washington, DC: U.S. Government Printing Office.

DOE/NV, see U.S. Department of Energy, Nevada Operations Office.

Forsgren, F. (IT Corporation). 1998. Memorandum to R. Jackson (IT) entitled "CAU 252, CAS 25-07-04 Sampling Report," 03 March. Las Vegas, NV.

ITLV, see IT Corporation, Las Vegas Office.

IT Corporation, Las Vegas Office. 1994 and 1997. Project files for CAU 252, CAS 25-07-04, Decontamination Pad. Las Vegas, NV.

NAC, see Nevada Administrative Code.

Nevada Administrative Code. 1998. NAC 445A.2272, "Contamination of Soils Establishment of Action Levels." Carson City, NV: Nevada Division of Environmental Protection.

Pan Am, see Pan American World Airways, Inc.

Pan American World Airways, Inc. 1966. Detailed site plan engineering drawing for the "Mobile Radiation Check Point Site, Detail Site Plan ETS-1 (only)," AUX-PAA-0061. Mercury, NV: Archives and Records Center.

Pan American World Airways, Inc. 1968. Six as-built engineering drawings for the "Mobile Radiation Checkpoint Site 'H' and 'K' Intersection," NRDS-SF-P29/V-1, C-1, C-2, M1, E1, E-2. Mercury, NV: Archives and Records Center.

SNPO, see Space Nuclear Propulsion Office.

Space Nuclear Propulsion Office. 1970. NRDS Master Plan 1969-1970, U.S. Government Memorandum dated 29 September from W.L. Walker distributing the Master Plan to several SNPO personnel. Las Vegas, NV. 
U.S. Department of Energy, Nevada Operations Office. 1984. Nevada Test Site Area 25 Radiological Survey and Cleanup Project 1974-1983 (A Revised Final Report), December, DOE/NV/10327--5, Rev. 1. Las Vegas, NV.

U.S. Department of Energy, Nevada Operations Office. 1996a. Final Environmental Impact Statement for the Nevada Test Site and Off-Site Locations in the State of Nevada, DOE/EIS 0243. Las Vegas, NV.

U.S. Department of Energy, Nevada Operations Office. 1996b. Industrial Sites Quality Assurance Project Plan, DOE/NV--372. Las Vegas, NV.

U.S. Environmental Protection Agency. 1996. Test Methods for Evaluating Solid Waste, Physical/Chemical Methods, SW-846, Third Edition, CD ROM, PB97-501928GEI. Washington, DC.

U.S. Environmental Protection Agency. 1998. Memorandum from S.J. Smucker regarding Region 9 Preliminary Remediation Goals (PRGs), 1 August. San Francisco, CA. 


\section{Appendix B}

\section{Project Organization}




\section{B.1.0 Project Organization}

The DOE/NV Industrial Sites Project Manager is Janet Appenzeller-Wing and her telephone number is (702) 295-0461.

The names of the project Health and Safety Officer and the Quality Assurance Officer can be found in the appropriate DOE/NV plan. However, personnel are subject to change, and it is suggested that the Project Manager be contacted for further information. The Task Manager will be identified in the FFACO Biweekly Activity Report prior to the start of field activities. 


\section{Appendix C}

Laboratory Chemical, Toxicity Characteristic Leaching

Procedure, and Radiochemistry Analytical Requirements for Industrial Sites 
Table C.1-1

Laboratory Chemical, Toxicity Characteristic Leaching Procedure, and
Radiochemistry Analytical Requirements for Industrial Sites

(Page 1 of 6)

\begin{tabular}{|c|c|c|c|c|c|c|}
\hline $\begin{array}{c}\text { Parameter or } \\
\text { Analyte }\end{array}$ & $\begin{array}{l}\text { Medium or } \\
\text { Matrix }\end{array}$ & $\begin{array}{l}\text { Analytical } \\
\text { Method }\end{array}$ & $\begin{array}{c}\text { Minimum } \\
\text { Reporting Limit }\end{array}$ & $\begin{array}{l}\text { Regulatory } \\
\text { Limit }\end{array}$ & $\begin{array}{c}\text { Relative } \\
\text { Percent } \\
\text { Difference } \\
\text { (RPD) }^{\mathrm{a}} \\
\end{array}$ & $\begin{array}{c}\text { Percent } \\
\text { Recovery } \\
(\% R)^{\mathrm{b}}\end{array}$ \\
\hline \multicolumn{7}{|c|}{ ORGANICS } \\
\hline \multirow{2}{*}{$\begin{array}{l}\text { Total Volatile } \\
\text { Organic Compounds } \\
\text { (VOCs) }\end{array}$} & Water & \multirow{2}{*}{$8260 \mathrm{~B}^{\mathrm{c}}$} & \multirow{2}{*}{$\begin{array}{l}\text { Analyte-specific } \\
\text { estimated } \\
\text { quantitation limits }^{d}\end{array}$} & \multirow{2}{*}{$\begin{array}{c}\text { Not Applicable } \\
\text { (NA) }\end{array}$} & $14^{\mathrm{e}}$ & $61-145^{\mathrm{e}}$ \\
\hline & Soil & & & & $24^{\mathrm{e}}$ & $59-172^{\mathrm{e}}$ \\
\hline \multicolumn{7}{|l|}{$\begin{array}{c}\text { Toxicity } \\
\text { Characteristic } \\
\text { Leaching Procedure } \\
\text { (TCLP) VOCs }\end{array}$} \\
\hline Benzene & \multirow{10}{*}{ Aqueous } & \multirow{10}{*}{$1311 / 8260 \mathrm{~B}^{\mathrm{c}}$} & $0.050 \mathrm{mg} / \mathrm{L}^{d}$ & $0.5 \mathrm{mg} / \mathrm{L}^{\mathrm{d}}$ & \multirow{10}{*}{$14^{\mathrm{e}}$} & \multirow{10}{*}{$61-145^{e}$} \\
\hline $\begin{array}{c}\text { Carbon } \\
\text { Tetrachloride }\end{array}$ & & & $0.050 \mathrm{mg} / \mathrm{L}^{\mathrm{d}}$ & $0.5 \mathrm{mg} / \mathrm{L}^{\mathrm{d}}$ & & \\
\hline Chlorobenzene & & & $0.050 \mathrm{mg} / \mathrm{L}^{d}$ & $100 \mathrm{mg} / \mathrm{L}^{d}$ & & \\
\hline Chloroform & & & $0.050 \mathrm{mg} / \mathrm{L}^{d}$ & $6 \mathrm{mg} / \mathrm{L}^{\mathrm{d}}$ & & \\
\hline 1,2-Dichloroethane & & & $0.050 \mathrm{mg} / \mathrm{L}^{d}$ & $0.5 \mathrm{mg} / \mathrm{L}^{d}$ & & \\
\hline 1,1-Dichloroethene & & & $0.050 \mathrm{mg} / \mathrm{L}^{d}$ & $0.7 \mathrm{mg} / \mathrm{L}^{\mathrm{d}}$ & & \\
\hline Methyl Ethyl Ketone & & & $0.050 \mathrm{mg} / \mathrm{L}^{\mathrm{d}}$ & $200 \mathrm{mg} / \mathrm{L}^{\mathrm{d}}$ & & \\
\hline Tetrachloroethene & & & $0.050 \mathrm{mg} / \mathrm{L}^{d}$ & $0.7 \mathrm{mg} / \mathrm{L}^{\mathrm{d}}$ & & \\
\hline Trichloroethene & & & $0.050 \mathrm{mg} / \mathrm{L}^{d}$ & $0.5 \mathrm{mg} / \mathrm{L}^{\mathrm{d}}$ & & \\
\hline Vinyl Chloride & & & $0.050 \mathrm{mg} / \mathrm{L}^{d}$ & $0.2 \mathrm{mg} / \mathrm{L}^{\mathrm{d}}$ & & \\
\hline \multirow{2}{*}{$\begin{array}{l}\text { Total Semivolatile } \\
\text { Organic Compounds } \\
\text { (SVOCs) }\end{array}$} & Water & \multirow{2}{*}{$8270 C^{c}$} & \multirow{2}{*}{$\begin{array}{l}\text { Analyte-specific } \\
\text { estimated } \\
\text { quantitation limits }^{d}\end{array}$} & \multirow{2}{*}{ NA } & $50^{e}$ & $9-127^{e}$ \\
\hline & Soil & & & & $50^{\mathrm{e}}$ & $11-142^{\mathrm{e}}$ \\
\hline \multicolumn{7}{|l|}{ TCLP SVOCs } \\
\hline o-Cresol & \multirow{6}{*}{ Aqueous } & \multirow{6}{*}{$1311 / 8270 C^{c}$} & $0.10 \mathrm{mg} / \mathrm{L}^{d}$ & $200 \mathrm{mg} / \mathrm{L}^{d}$ & \multirow{6}{*}{$50^{e}$} & \multirow{6}{*}{$9-127^{e}$} \\
\hline m-Cresol & & & $0.10 \mathrm{mg} / \mathrm{L}^{\mathrm{d}}$ & $200 \mathrm{mg} / \mathrm{L}^{d}$ & & \\
\hline $\mathrm{p}$-Cresol & & & $0.10 \mathrm{mg} / \mathrm{L}^{\mathrm{d}}$ & $200 \mathrm{mg} / \mathrm{L}^{d}$ & & \\
\hline Cresol (total) & & & $0.30 \mathrm{mg} / \mathrm{L}^{\mathrm{d}}$ & $200 \mathrm{mg} / \mathrm{L}^{\mathrm{d}}$ & & \\
\hline $\begin{array}{l}\text { 1,4-Dichloro- } \\
\text { benzene }\end{array}$ & & & $0.10 \mathrm{mg} / \mathrm{L}^{\mathrm{d}}$ & $7.5 \mathrm{mg} / \mathrm{L}^{\mathrm{d}}$ & & \\
\hline 2,4-Dinitrotoluene & & & $0.10 \mathrm{mg} / \mathrm{L}^{\mathrm{d}}$ & $0.13 \mathrm{mg} / \mathrm{L}^{\mathrm{d}}$ & & \\
\hline
\end{tabular}


Table C.1-1

\section{Laboratory Chemical, Toxicity Characteristic Leaching Procedure, and Radiochemistry Analytical Requirements for Industrial Sites}

(Page 2 of 6 )

\begin{tabular}{|c|c|c|c|c|c|c|}
\hline $\begin{array}{l}\text { Parameter or } \\
\text { Analyte }\end{array}$ & $\begin{array}{l}\text { Medium or } \\
\text { Matrix }\end{array}$ & $\begin{array}{l}\text { Analytical } \\
\text { Method }\end{array}$ & $\begin{array}{c}\text { Minimum } \\
\text { Reporting Limit }\end{array}$ & $\begin{array}{l}\text { Regulatory } \\
\text { Limit }\end{array}$ & $\begin{array}{c}\text { Relative } \\
\text { Percent } \\
\text { Difference } \\
\text { (RPD) }^{\mathrm{a}}\end{array}$ & $\begin{array}{c}\text { Percent } \\
\text { Recovery } \\
(\% R)^{b}\end{array}$ \\
\hline $\begin{array}{l}\text { Hexachloro- } \\
\text { benzene }\end{array}$ & \multirow{8}{*}{ Aqueous } & \multirow{8}{*}{$1311 / 8270 \mathrm{C}^{\mathrm{c}}$} & $0.10 \mathrm{mg} / \mathrm{L}^{\mathrm{d}}$ & $0.13 \mathrm{mg} / \mathrm{L}^{\mathrm{d}}$ & \multirow{8}{*}{$50^{e}$} & \multirow{8}{*}{$9-127^{e}$} \\
\hline $\begin{array}{l}\text { Hexachloro- } \\
\text { butadiene }\end{array}$ & & & $0.10 \mathrm{mg} / \mathrm{L}^{\mathrm{d}}$ & $0.5 \mathrm{mg} / \mathrm{L}^{\mathrm{d}}$ & & \\
\hline $\begin{array}{l}\text { Hexachloro- } \\
\text { ethane }\end{array}$ & & & $0.10 \mathrm{mg} / \mathrm{L}^{\mathrm{d}}$ & $3 \mathrm{mg} / \mathrm{L}^{\mathrm{d}}$ & & \\
\hline Nitrobenzene & & & $0.10 \mathrm{mg} / \mathrm{L}^{d}$ & $2 \mathrm{mg} / \mathrm{L}^{\mathrm{d}}$ & & \\
\hline $\begin{array}{l}\text { Pentachloro- } \\
\text { phenol }\end{array}$ & & & $0.50 \mathrm{mg} / \mathrm{L}^{\mathrm{d}}$ & $100 \mathrm{mg} / \mathrm{L}^{\mathrm{d}}$ & & \\
\hline Pyridine & & & $0.10 \mathrm{mg} / \mathrm{L}^{\mathrm{d}}$ & $5 \mathrm{mg} / \mathrm{L}^{\mathrm{d}}$ & & \\
\hline $\begin{array}{l}\text { 2,4,5-Trichloro- } \\
\text { phenol }\end{array}$ & & & $0.10 \mathrm{mg} / \mathrm{L}^{\mathrm{d}}$ & $400 \mathrm{mg} / \mathrm{L}^{\mathrm{d}}$ & & \\
\hline $\begin{array}{l}\text { 2,4,6-Trichloro- } \\
\text { phenol }\end{array}$ & & & $0.10 \mathrm{mg} / \mathrm{L}^{\mathrm{d}}$ & $2 \mathrm{mg} / \mathrm{L}^{\mathrm{d}}$ & & \\
\hline \multirow{2}{*}{$\begin{array}{c}\text { Total } \\
\text { Pesticides }\end{array}$} & Water & \multirow{2}{*}{$8081 A^{c}$} & \multirow{2}{*}{$\begin{array}{l}\text { Analyte-specific } \\
(\mathrm{CRQL})^{\mathrm{e}}\end{array}$} & \multirow{2}{*}{ NA } & $27^{e}$ & $38-131^{e}$ \\
\hline & Soil & & & & $50^{e}$ & $23-139^{e}$ \\
\hline \multicolumn{7}{|l|}{$\begin{array}{c}\text { TCLP } \\
\text { Pesticides } \\
\end{array}$} \\
\hline Chlordane & \multirow{7}{*}{ Aqueous } & \multirow{7}{*}{$1311 / 8081 A^{c}$} & $0.0005 \mathrm{mg} / \mathrm{L}^{\mathrm{e}}$ & $0.03 \mathrm{mg} / \mathrm{L}^{d}$ & \multirow{7}{*}{$27^{e}$} & \multirow{7}{*}{$38-131^{e}$} \\
\hline Endrin & & & $0.001 \mathrm{mg} / \mathrm{L}^{\mathrm{e}}$ & $0.02 \mathrm{mg} / \mathrm{L}^{d}$ & & \\
\hline Heptachlor & & & $0.0005 \mathrm{mg} / \mathrm{L}^{\mathrm{e}}$ & $0.008 \mathrm{mg} / \mathrm{L}^{\mathrm{d}}$ & & \\
\hline $\begin{array}{l}\text { Heptachlor } \\
\text { Epoxide }\end{array}$ & & & $0.0005 \mathrm{mg} / \mathrm{L}^{\mathrm{e}}$ & $0.008 \mathrm{mg} / \mathrm{L}^{\mathrm{d}}$ & & \\
\hline $\begin{array}{l}\text { gamma-BHC } \\
\text { (Lindane) }\end{array}$ & & & $0.0005 \mathrm{mg} / \mathrm{L}^{\mathrm{e}}$ & $0.4 \mathrm{mg} / \mathrm{L}^{\mathrm{d}}$ & & \\
\hline Methoxychlor & & & $0.005 \mathrm{mg} / \mathrm{L}^{\mathrm{e}}$ & $10 \mathrm{mg} / \mathrm{L}^{\mathrm{d}}$ & & \\
\hline Toxaphene & & & $0.05 \mathrm{mg} / \mathrm{L}^{\mathrm{e}}$ & $0.5 \mathrm{mg} / \mathrm{L}^{\mathrm{d}}$ & & \\
\hline \multirow[b]{2}{*}{$\begin{array}{c}\text { Polychlorinated } \\
\text { Biphenyls (PCBs) }\end{array}$} & Water & \multirow[b]{2}{*}{$8082^{c}$} & \multirow{2}{*}{$\begin{array}{c}\text { Analyte-specific } \\
\text { contract required } \\
\text { quantitation limits } \\
(\mathrm{CRQL})^{\mathrm{e}}\end{array}$} & \multirow[b]{2}{*}{ NA } & \multirow[b]{2}{*}{ Lab-specific $^{\dagger}$} & \multirow[b]{2}{*}{ Lab-specific } \\
\hline & Soil & & & & & \\
\hline \multirow{2}{*}{$\begin{array}{c}\text { Total } \\
\text { Herbicides }\end{array}$} & Water & \multirow{2}{*}{$8151 A^{c}$} & $1.3 \mu \mathrm{g} / \mathrm{L}^{\mathrm{c}}$ & \multirow{2}{*}{ NA } & \multirow{2}{*}{ Lab-specific $^{\dagger}$} & \multirow{2}{*}{ Lab-specific } \\
\hline & Soil & & $66 \mu \mathrm{g} / \mathrm{kg}^{\mathrm{c}}$ & & & \\
\hline \multicolumn{7}{|l|}{$\begin{array}{c}\text { TCLP } \\
\text { Herbicides }\end{array}$} \\
\hline $2,4-D$ & \multirow{2}{*}{ Aqueous } & \multirow{2}{*}{$1311 / 8151 A^{c}$} & $0.002 \mathrm{mg} / \mathrm{L}^{d}$ & $10 \mathrm{mg} / \mathrm{L}^{\mathrm{d}}$ & \multirow{2}{*}{ Lab-specific $^{f}$} & \multirow{2}{*}{ Lab-specific ${ }^{\dagger}$} \\
\hline $2,4,5-\mathrm{TP}$ & & & $0.00075 \mathrm{mg} / \mathrm{L}^{\mathrm{d}}$ & $1 \mathrm{mg} / \mathrm{L}^{\mathrm{d}}$ & & \\
\hline
\end{tabular}


Table C.1-1

\section{Laboratory Chemical, Toxicity Characteristic Leaching Procedure, and Radiochemistry Analytical Requirements for Industrial Sites}

(Page 3 of 6 )

\begin{tabular}{|c|c|c|c|c|c|c|}
\hline $\begin{array}{l}\text { Parameter or } \\
\text { Analyte }\end{array}$ & $\begin{array}{l}\text { Medium or } \\
\text { Matrix }\end{array}$ & $\begin{array}{l}\text { Analytical } \\
\text { Method }\end{array}$ & $\begin{array}{c}\text { Minimum } \\
\text { Reporting Limit }\end{array}$ & $\begin{array}{l}\text { Regulatory } \\
\text { Limit }\end{array}$ & $\begin{array}{c}\text { Relative } \\
\text { Percent } \\
\text { Difference } \\
\text { (RPD) }^{\mathrm{a}}\end{array}$ & $\begin{array}{c}\text { Percent } \\
\text { Recovery } \\
(\% R)^{b}\end{array}$ \\
\hline \multirow{4}{*}{$\begin{array}{c}\text { Total Petroleum } \\
\text { Hydrocarbons (TPH) }\end{array}$} & $\begin{array}{c}\text { Water } \\
\text { Gasoline }\end{array}$ & \multirow{4}{*}{ 8015B modified ${ }^{c}$} & $0.1 \mathrm{mg} / \mathrm{L}^{\mathrm{g}}$ & \multirow{4}{*}{ NA } & \multirow{4}{*}{ Lab-specific $^{f}$} & \multirow{4}{*}{ Lab-specific $^{\dagger}$} \\
\hline & Soil Gasoline & & $0.5 \mathrm{mg} / \mathrm{kg}^{\mathrm{g}}$ & & & \\
\hline & Water Diesel & & $0.5 \mathrm{mg} / \mathrm{L}^{\mathrm{g}}$ & & & \\
\hline & Soil Diesel & & $25 \mathrm{mg} / \mathrm{kg}^{\mathrm{g}}$ & & & \\
\hline \multirow{2}{*}{ Explosives } & Water & \multirow{2}{*}{$8330^{c}$} & $14 \mu \mathrm{g} / \mathrm{L}^{\mathrm{c}}$ & \multirow{2}{*}{ NA } & \multirow{2}{*}{ Lab-specific $^{\dagger}$} & \multirow{2}{*}{ Lab-specific $^{f}$} \\
\hline & Soil & & $2.2 \mathrm{mg} / \mathrm{kg}^{\mathrm{c}}$ & & & \\
\hline \multirow{2}{*}{$\begin{array}{c}\text { Polychlorinated } \\
\text { Dioxins and Furans }\end{array}$} & Water & \multirow{2}{*}{$8280 \mathrm{~A} / 8290^{c}$} & $0.05 \mu \mathrm{g} / \mathrm{L}^{\mathrm{c}}$ & \multirow{2}{*}{ NA } & \multirow{2}{*}{ Lab-specific $^{f}$} & \multirow{2}{*}{ Lab-specific } \\
\hline & Soil & & $5 \mu \mathrm{g} / \mathrm{kg}^{\mathrm{c}}$ & & & \\
\hline \multicolumn{7}{|c|}{ INORGANICS } \\
\hline \multicolumn{7}{|l|}{$\begin{array}{c}\text { Total Resource } \\
\text { Conservation and } \\
\text { Recovery Act } \\
\text { (RCRA) Metals }\end{array}$} \\
\hline \multirow{2}{*}{ Arsenic } & Water & $6010 \mathrm{~B} / 7470 \mathrm{~A}^{\mathrm{c}}$ & $10 \mu \mathrm{g} / \mathrm{L}^{\mathrm{g}, \mathrm{h}}$ & \multirow{16}{*}{ NA } & \multirow{16}{*}{$20^{h}$} & \multirow{16}{*}{$75-125^{\mathrm{h}}$} \\
\hline & Soil & $6010 B / 7471 A^{c}$ & $1 \mathrm{mg} / \mathrm{kg}^{\mathrm{g}, \mathrm{h}}$ & & & \\
\hline \multirow{2}{*}{ Barium } & Water & $6010 \mathrm{~B} / 7470 \mathrm{~A}^{\mathrm{c}}$ & $200 \mu \mathrm{g} / \mathrm{L}^{\mathrm{g}, \mathrm{h}}$ & & & \\
\hline & Soil & $6010 B / 7471 A^{c}$ & $20 \mathrm{mg} / \mathrm{kg}^{\mathrm{g}, \mathrm{h}}$ & & & \\
\hline \multirow{2}{*}{ Cadmium } & Water & $6010 \mathrm{~B} / 7470 \mathrm{~A}^{\mathrm{c}}$ & $5 \mu \mathrm{g} / \mathrm{L}^{\mathrm{g}, \mathrm{h}}$ & & & \\
\hline & Soil & $6010 \mathrm{~B} / 7471 \mathrm{~A}^{\mathrm{c}}$ & $0.5 \mathrm{mg} / \mathrm{kg}^{\mathrm{g}, \mathrm{h}}$ & & & \\
\hline \multirow{2}{*}{ Chromium } & Water & $6010 \mathrm{~B} / 7470 \mathrm{~A}^{\mathrm{c}}$ & $10 \mu \mathrm{g} / \mathrm{L}^{\mathrm{g}, \mathrm{h}}$ & & & \\
\hline & Soil & $6010 \mathrm{~B} / 7471 \mathrm{~A}^{\mathrm{c}}$ & $1 \mathrm{mg} / \mathrm{kg}^{\mathrm{g}, \mathrm{h}}$ & & & \\
\hline \multirow{2}{*}{ Lead } & Water & $6010 \mathrm{~B} / 7470 \mathrm{~A}^{\mathrm{c}}$ & $3 \mu \mathrm{g} / \mathrm{L}^{\mathrm{g}, \mathrm{h}}$ & & & \\
\hline & Soil & $6010 \mathrm{~B} / 7471 \mathrm{~A}^{\mathrm{c}}$ & $0.3 \mathrm{mg} / \mathrm{kg}^{\mathrm{g}, \mathrm{h}}$ & & & \\
\hline \multirow{2}{*}{ Mercury } & Water & $6010 \mathrm{~B} / 7470 \mathrm{~A}^{\mathrm{c}}$ & $0.2 \mu \mathrm{g} / \mathrm{L}^{\mathrm{g}, \mathrm{h}}$ & & & \\
\hline & Soil & $6010 \mathrm{~B} / 7471 \mathrm{~A}^{\mathrm{c}}$ & $0.1 \mathrm{mg} / \mathrm{kg}^{\mathrm{g}, \mathrm{h}}$ & & & \\
\hline \multirow{2}{*}{ Selenium } & Water & $6010 \mathrm{~B} / 7470 \mathrm{~A}^{\mathrm{c}}$ & $5 \mu \mathrm{g} / \mathrm{L}^{\mathrm{g}, \mathrm{h}}$ & & & \\
\hline & Soil & $6010 \mathrm{~B} / 7471 \mathrm{~A}^{\mathrm{c}}$ & $0.5 \mathrm{mg} / \mathrm{kg}^{\mathrm{g}, \mathrm{h}}$ & & & \\
\hline \multirow{2}{*}{ Silver } & Water & $6010 \mathrm{~B} / 7470 \mathrm{~A}^{\mathrm{c}}$ & $10 \mu \mathrm{g} / \mathrm{L}^{\mathrm{g}, \mathrm{h}}$ & & & \\
\hline & Soil & $6010 \mathrm{~B} / 7471 \mathrm{~A}^{\mathrm{c}}$ & $1 \mathrm{mg} / \mathrm{kg}^{\mathrm{g}, \mathrm{h}}$ & & & \\
\hline
\end{tabular}


Table C.1-1

Laboratory Chemical, Toxicity Characteristic Leaching Procedure, and Radiochemistry Analytical Requirements for Industrial Sites

(Page 4 of 6 )

\begin{tabular}{|c|c|c|c|c|c|c|}
\hline $\begin{array}{l}\text { Parameter or } \\
\text { Analyte }\end{array}$ & $\begin{array}{l}\text { Medium or } \\
\text { Matrix }\end{array}$ & $\begin{array}{l}\text { Analytical } \\
\text { Method }\end{array}$ & $\begin{array}{c}\text { Minimum } \\
\text { Reporting Limit }\end{array}$ & $\begin{array}{l}\text { Regulatory } \\
\text { Limit }\end{array}$ & $\begin{array}{c}\text { Relative } \\
\text { Percent } \\
\text { Difference } \\
\text { (RPD) }^{\mathrm{a}}\end{array}$ & $\begin{array}{c}\text { Percent } \\
\text { Recovery } \\
(\% \mathrm{R})^{\mathrm{b}}\end{array}$ \\
\hline \multicolumn{7}{|l|}{$\begin{array}{l}\text { TCLP RCRA } \\
\text { Metals }\end{array}$} \\
\hline Arsenic & \multirow{8}{*}{ Aqueous } & \multirow{8}{*}{$\begin{array}{l}1311 / 6010 B^{c} \\
1311 / 7470 A^{c}\end{array}$} & $0.10 \mathrm{mg} / \mathrm{L}^{\mathrm{g}, \mathrm{h}}$ & $5 \mathrm{mg} / \mathrm{L}^{\mathrm{d}}$ & \multirow{8}{*}{$20^{h}$} & \multirow{8}{*}{$75-125^{h}$} \\
\hline Barium & & & $2 \mathrm{mg} / \mathrm{L}^{\mathrm{g}, \mathrm{h}}$ & $100 \mathrm{mg} / \mathrm{L}^{d}$ & & \\
\hline Cadmium & & & $0.05 \mathrm{mg} / \mathrm{L}^{\mathrm{g}, \mathrm{h}}$ & $1 \mathrm{mg} / \mathrm{L}^{\mathrm{d}}$ & & \\
\hline Chromium & & & $0.10 \mathrm{mg} / \mathrm{L}^{\mathrm{g}, \mathrm{h}}$ & $5 \mathrm{mg} / \mathrm{L}^{\mathrm{d}}$ & & \\
\hline Lead & & & $0.03 \mathrm{mg} / \mathrm{L}^{\mathrm{g}, \mathrm{h}}$ & $5 \mathrm{mg} / \mathrm{L}^{\mathrm{d}}$ & & \\
\hline Mercury & & & $0.002 \mathrm{mg} / \mathrm{L}^{\mathrm{g}, \mathrm{h}}$ & $0.2 \mathrm{mg} / \mathrm{L}^{\mathrm{d}}$ & & \\
\hline Selenium & & & $0.05 \mathrm{mg} / \mathrm{L}^{g, h}$ & $1 \mathrm{mg} / \mathrm{L}^{\mathrm{d}}$ & & \\
\hline Silver & & & $0.10 \mathrm{mg} / \mathrm{L}^{\mathrm{g}, \mathrm{h}}$ & $5 \mathrm{mg} / \mathrm{L}^{\mathrm{d}}$ & & \\
\hline \multirow{2}{*}{ Cyanide } & Water & \multirow{2}{*}{$9010 \mathrm{~B}^{\mathrm{c}}$} & $0.01 \mathrm{mg} / \mathrm{L}^{\mathrm{h}}$ & \multirow{2}{*}{ NA } & \multirow{2}{*}{$20^{\text {h }}$} & \multirow{2}{*}{$75-125^{h}$} \\
\hline & Soil & & $1.0 \mathrm{mg} / \mathrm{kg}^{\mathrm{h}}$ & & & \\
\hline \multirow[b]{2}{*}{ Sulfide } & Water & \multirow[b]{2}{*}{$9030 \mathrm{~B} / 9034^{\mathrm{c}}$} & $0.4 \mathrm{mg} / \mathrm{L}^{\mathrm{c}}$ & \multirow[b]{2}{*}{ NA } & \multirow[b]{2}{*}{ Lab-specific $^{f}$} & \multirow[b]{2}{*}{ Lab-specific ${ }^{f}$} \\
\hline & $\begin{array}{l}\text { Soil or } \\
\text { Sediment }\end{array}$ & & $10 \mathrm{mg} / \mathrm{kg}^{\mathrm{g}}$ & & & \\
\hline \multirow{2}{*}{$\mathrm{pH} /$ Corrosivity } & Water & $9040 \mathrm{~B}^{\mathrm{c}}$ & \multirow{2}{*}{ NA } & $\mathrm{pH}>2^{\mathrm{i}}$ & \multirow{2}{*}{ Lab-specific $^{\dagger}$} & \multirow{2}{*}{ Lab-specific ${ }^{f}$} \\
\hline & Soil & $9045 C^{c}$ & & $\mathrm{pH}<12.5^{\mathrm{i}}$ & & \\
\hline \multirow[b]{2}{*}{ Ignitability } & Water & $1010^{c}$ & \multirow[b]{2}{*}{ NA } & $\begin{array}{l}\text { Flash Point } \\
<140^{\circ} F^{d}\end{array}$ & & \multirow[b]{2}{*}{ NA } \\
\hline & Soil & $1030^{c}$ & & $\begin{array}{c}\text { Burn Rate } \\
>2.2 \mathrm{~mm} / \mathrm{sec} \\
\text { nonmetals; } \\
>0.17 \mathrm{~mm} / \mathrm{sec} \\
\text { metals }\end{array}$ & NA & \\
\hline \multicolumn{7}{|c|}{ RADIOCHEMISTRY } \\
\hline \multirow{2}{*}{$\begin{array}{l}\text { Gamma-emitting } \\
\text { Radionuclides }^{j}\end{array}$} & Water & EPA $901.1^{\mathrm{k}}$ & \multirow{2}{*}{ Isotope-specific ${ }^{m}$} & \multirow{2}{*}{ NA } & 20 & \multirow{8}{*}{$\begin{array}{c}\text { Tracer Yield } \\
30-105 \\
\text { Laboratory } \\
\text { Control } \\
\text { Sample Yield } \\
80-120\end{array}$} \\
\hline & Soil & HASL $300^{\prime}$ & & & 35 & \\
\hline & Water & & $1 \mathrm{pCi} / \mathrm{L}$ & & 20 & \\
\hline $\begin{array}{l}\text { Isotopic } \\
\text { Plutonium }\end{array}$ & Soil & NAS-NS-3058 n,o & $\begin{array}{c}0.1 \mathrm{pCi} / \mathrm{g} \\
\mathrm{Pu}-238^{\mathrm{p}} \\
0.4 \mathrm{pCi} / \mathrm{g} \\
\mathrm{Pu}-239 / 240^{\mathrm{p}}\end{array}$ & NA & 35 & \\
\hline \multirow{2}{*}{$\begin{array}{l}\text { Isotopic } \\
\text { Uranium }\end{array}$} & Water & \multirow{2}{*}{ NAS-NS-3050 q,r } & $2 \mathrm{pCi} / \mathrm{L}$ & \multirow{2}{*}{ NA } & 20 & \\
\hline & Soil & & $1 \mathrm{pCi} / \mathrm{g}$ & & 35 & \\
\hline \multirow{2}{*}{ Strontium - $90^{j}$} & Water & SM $7500-\mathrm{Sr}^{\mathrm{s}}$ & $5 \mathrm{pCi} / \mathrm{L}$ & \multirow{2}{*}{ NA } & 20 & \\
\hline & Soil & Martin $79^{t}$ & $1 \mathrm{pCi} / \mathrm{g}^{\mathrm{u}}$ & & 35 & \\
\hline
\end{tabular}


Table C.1-1

Laboratory Chemical, Toxicity Characteristic Leaching Procedure, and Radiochemistry Analytical Requirements for Industrial Sites (Page 5 of 6 )

\begin{tabular}{|c|c|c|c|c|c|c|}
\hline $\begin{array}{c}\text { Parameter or } \\
\text { Analyte }\end{array}$ & $\begin{array}{l}\text { Medium or } \\
\text { Matrix }\end{array}$ & $\begin{array}{l}\text { Analytical } \\
\text { Method }\end{array}$ & $\begin{array}{c}\text { Minimum } \\
\text { Reporting Limit }\end{array}$ & $\begin{array}{c}\text { Regulatory } \\
\text { Limit }\end{array}$ & $\begin{array}{c}\text { Relative } \\
\text { Percent } \\
\text { Difference } \\
\text { (RPD) }^{\mathrm{a}}\end{array}$ & $\begin{array}{c}\text { Percent } \\
\text { Recovery } \\
(\% \mathrm{R})^{\mathrm{b}}\end{array}$ \\
\hline \multirow[b]{2}{*}{ Gross Alpha } & Water & EPA $900.0^{k}$ & $3 \mathrm{pCi} / \mathrm{L}^{v}$ & \multirow[b]{2}{*}{ NA } & 20 & \multirow{2}{*}{$\begin{array}{c}\text { Tracer Yield } \\
30-105 \\
\text { Laboratory } \\
\text { Control } \\
\text { Sample Yield } \\
80-120 \\
\end{array}$} \\
\hline & Soil & SM $7110^{s}$ & $3 \mathrm{pCi} / \mathrm{g}^{\mathrm{v}}$ & & 35 & \\
\hline \multirow[b]{2}{*}{ Gross Beta } & Water & EPA $900.0^{k}$ & $4 \mathrm{pCi} / \mathrm{L}^{\mathrm{v}}$ & \multirow[b]{2}{*}{ NA } & 20 & \multirow{2}{*}{$\begin{array}{c}\text { Tracer Yield } \\
\text { 30-105 } \\
\text { Laboratory } \\
\text { Control } \\
\text { Sample Yield } \\
80-120\end{array}$} \\
\hline & Soil & SM $7110^{s}$ & $4 \mathrm{pCi} / \mathrm{g}^{v}$ & & 35 & \\
\hline
\end{tabular}




\title{
Table C.1-1 \\ Laboratory Chemical, Toxicity Characteristic Leaching Procedure, and Radiochemistry Analytical Requirements for Industrial Sites (Page 6 of 6 )
}

\author{
${ }^{a} R P D$ is used to Calculate Precision \\ Precision is estimated from the relative percent difference of the concentrations measured for the matrix spike and matrix spike \\ duplicate analyses of unspiked field samples, or field duplicates of unspiked samples. It is calculated by: \\ $\mathrm{RPD}=100 \times\left\{\left(\left|\mathrm{C}_{1}-\mathrm{C}_{2}\right|\right) /\left[\left(\mathrm{C}_{1}+\mathrm{C}_{2}\right) / 2\right]\right\}$, where $\mathrm{C}_{1}=$ Concentration of the analyte in the first sample aliquot, $\mathrm{C}_{2}=$ Concentration of \\ the analyte in the second sample aliquot. \\ bo $R$ is used to Calculate Accuracy \\ Accuracy is assessed from the recovery of analytes spiked into a blank or sample matrix of interest, or from the recovery of \\ surrogate compounds spiked into each sample. The recovery of each spiked analyte is calculated by: $\% R=100 \times\left(C_{s}-C_{u} / C_{n}\right)$, \\ where $\mathrm{C}_{\mathrm{s}}=$ Concentration of the analyte in the spiked sample, $\mathrm{C}_{\mathrm{u}}=$ Concentration of the analyte in the unspiked sample, \\ $\mathrm{C}_{\mathrm{n}}=$ Concentration increase that should result from spiking the sample \\ 'U.S. Environmental Protection Agency's (EPAs) Test Methods for Evaluating Solid Waste, 3rd Edition, Parts 1-4, SW-846 \\ (EPA, 1996) \\ 'Estimated Quantitation Limit as given in SW-846 (EPA, 1996) \\ EEPA Contract Laboratory Program Statement of Work for Organic Analysis (EPA, 1988b; 1990; 1991; and 1994b) \\ ${ }^{f}$ In-House Generated RPD and \%R Performance Criteria \\ It is necessary for laboratories to develop in-house performance criteria and compare them to those in the methods. The \\ laboratory begins by analyzing 15-20 samples of each matrix and calculating the mean \%R for each analyte. The standard \\ deviation (SD) of each \%R is then calculated, and the warning and control limits for each analyte are established at \pm 2 SD and \\ $\pm 3 \mathrm{SD}$ from the mean, respectively. If the warning limit is exceeded during the analysis of any sample delivery group (SDG), \\ the laboratory institutes corrective action to bring the analytical system back into control. If the control limit is exceeded, the \\ sample results for that SDG are considered unacceptable. These limits are reviewed after every 20-30 field samples of the \\ same matrix and are updated at least semiannually. The laboratory tracks trends in both performance and control limits by the \\ use of control charts. The laboratory's compliance with these requirements is confirmed as part of an annual laboratory audit. \\ Similar procedures are followed in order to generate acceptance criteria for precision measurements. \\ ${ }^{9}$ Industrial Sites Quality Assurance Project Plan (DOE/NV, 1996) \\ hEPA Contract Laboratory Program Statement of Work for Inorganic Analysis (EPA, 1988a; 1993; and 1994a) \\ 'RCRA Regulations and Keyword Index, 1998 Edition \\ IIsotopic minimum detectable concentrations are defined during the DQO process and specified in the CAIP as applicable \\ ${ }^{\mathrm{k}}$ Prescribed Procedures for Measurements of Radioactivity in Drinking Water (EPA, 1980) or equivalent method \\ 'Environmental Measurements Laboratory Procedures Manual (DOE, 1997) or equivalent method \\ mIsotope-Specific Minimum Reporting Limit to be specified in CAIP \\ ${ }^{\mathrm{n}}$ The Radiochemistry of Plutonium (Coleman, 1965) or equivalent method \\ - Separation and Preconcentration of Actinides from Acidic Media by Extraction Chromatography (Horwitz, et al., 1993) or \\ equivalent method \\ ${ }^{\mathrm{P}}$ The Nevada Test Site Performance Objective Criteria requirement for certifying that hazardous waste has no added radioactivity \\ requires that the total plutonium (the sum of the Pu-238, 239, 240 concentrations) not exceed $0.5 \mathrm{pCi} / \mathrm{g}$ (BN, 1995) \\ ${ }^{\mathrm{q}}$ The Radiochemistry of Uranium (Grindler, 1962) or equivalent method \\ 'Separation and Preconcentration of Uranium from Acidic Media by Extraction Chromatography (Horwitz, et al., 1992) or \\ equivalent method

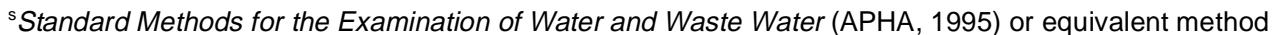 \\ 'Determination of Strontium-89 and -90 in soil with Total Sample Decomposition (Analytical Chemistry, 1979) or equivalent \\ method \\ "The $1.0 \mathrm{pCi} / \mathrm{g}$ concentration is approximately twice the concentration of fallout $\mathrm{Sr}-90$ in background surface soils reported in the \\ Environmental Monitoring Report for the Proposed Ward Valley California Low-Level Radioactive Waste Facility \\ (Atlan-Tech, 1992) \\ "Minimum Reporting Limits (MRLs) for Radiological Contaminants of Potential Concern for the Area 25 Engine Test Stand 1 \\ Decontamination Pad, Corrective Action Unit (CAU) 252 (Adams, 1999) \\ Definitions: \\ $\mu \mathrm{g} / \mathrm{kg}=$ Microgram(s) per kilogram \\ $\mathrm{mg} / \mathrm{kg}=$ Milligram(s) per kilogram \\ $\mathrm{pCi} / \mathrm{L}=$ Picocurie(s) per liter \\ $\mathrm{mg} / \mathrm{L}=$ Milligram(s) per liter \\ $\mathrm{pCi} / \mathrm{g}=$ Picocurie(s) per gram \\ $\mu \mathrm{g} / \mathrm{L}=$ Microgram(s) per liter
}




\section{C.1.0 References}

Adams, S.R. (IT Corporation). 1999. Memorandum to Juliana Herrington regarding the "Minimum Reporting Limits (MRLS) for Radiological Contaminants of Potential Concern for the Area 25 Engine Test Stand 1 Decontamination Pad, Corrective Action Unit (CAU) 252," 17 August. Las Vegas, NV.

APHA, see American Public Health Association.

American Public Health Association. 1995. Standard Methods for the Examination of Water and Waste Water, 19th Edition. Washington, D.C.

Analytical Chemistry. 1979. Determination of Strontium-89 and -90 in Soil with Total Sample Decomposition, October.

Atlan-Tech. 1992. Environmental Monitoring Report for the Proposed Ward Valley California Low-Level Radioactive Waste Facility. Roswell, GA.

BN, see Bechtel Nevada.

Bechtel Nevada. 1995. Nevada Test Site Performance Objective for Certification of Nonradioactive Hazardous Waste, Rev.0, G-E11/96.01. Las Vegas, NV.

Coleman, G.H. 1965. The Radiochemistry of Plutonium, NAS-NS-3058. Washington, DC: National Academy of Sciences.

Grindler, J.E. 1962. The Radiochemistry of Uranium, NAS-NS3050. Washington, DC: National Academy of Science.

Horwitz, E.P., M.L. Dietz, R. Chiarizia, and H. Diamond. 1992. "Separation and Preconcentration of Uranium from Acidic Media by Extraction Chromatography." In Analyticda Chimica Acta, 266:25-37. Amsterdam, The Netherlands: Elsevier Publishers, B.V.

Horwitz, E.P., R. Chiarizia, M.L. Dietz, H. Diamond, and D.M. Nelson. 1993. "Separation and Preconcentration of Actinides from Acidic Media by Extraction Chromatography." In Analyticda Chimica Acta, 281:361-372. Amsterdam, The Netherlands:

Elsevier Publishers, B.V.

RCRA Regulations and Keyword Index. 1998. ISSN 1074-1364. New York, NY: Elsevier Science, Inc.

U.S. Department of Energy. 1997. Environmental Measurements Laboratory Procedures Manual, HASL-300, 28th Edition, Vol. 1. New York, NY. 
U.S. Department of Energy, Nevada Operations Office. 1996. Industrial Sites Quality Assurance Project Plan, Nevada Test Site, Nevada, DOE/NV--372. Las Vegas, NV.

U.S. Environmental Protection Agency. 1980. Prescribed Procedures for Measurements of Radioactivity in Drinking Water, EPA-600/4-80-032. Washington, DC.

U.S. Environmental Protection Agency. 1988a. Contract Laboratory Program Statement of Work for Inorganic Analysis, ILMO 3.0. Washington, DC.

U.S. Environmental Protection Agency. 1988b. Contract Laboratory Program Statement of Work for Organic Analysis, February. Washington, DC.

U.S. Environmental Protection Agency. 1990. Contract Laboratory Program Statement of Work for Organic Analysis, March. Washington, DC.

U.S. Environmental Protection Agency. 1991. Contract Laboratory Program Statement of Work for Organic Analysis, OLMO 1.8. Washington, DC.

U.S. Environmental Protection Agency. 1993. Contract Laboratory Program Statement of Work for Inorganic Analysis, ILMO 3.0. Washington, DC.

U.S. Environmental Protection Agency. 1994a. Contract Laboratory Program Statement of Work for Inorganic Analysis, ILMO 4.0. Washington, DC.

U.S. Environmental Protection Agency. 1994b. Contract Laboratory Program Statement of Work for Organic Analysis, OLMO 3.1. Washington, DC.

U.S. Environmental Protection Agency. 1996. Test Methods for Evaluating Solid Waste, Physical/Chemical Methods, SW-846, $3^{\text {rd }}$ Edition (which includes updates to 1986, 1992, and 1994 revisions), CD-ROM. Washington, DC. 
Appendix D

NDEP Comment Responses 
NEVADA ENVIRONMENTAL RESTORATION PROJECT

\section{DOCUMENT REVIEW SHEET}

\begin{tabular}{|c|c|c|c|c|c|}
\hline \multicolumn{4}{|c|}{$\begin{array}{l}\text { 1. Document Title/Number: Draft Corrective Action Investigation Plan for Corrective Action Unit 252: Area } 25 \text { Engine } \\
\text { Test Stand-1 Decontamination Pad, Nevada Test Site, Nevada }\end{array}$} & \multicolumn{2}{|c|}{ 2. Document Date: June 1999} \\
\hline \multicolumn{4}{|c|}{ 3. Revision Number: 0} & \multicolumn{2}{|c|}{$\begin{array}{l}\text { 4. Originator/Organization: IT } \\
\text { Corporation }\end{array}$} \\
\hline \multicolumn{4}{|c|}{ 5. Responsible DOE/NV ERP Project Mgr.: Janet Appenzeller-Wing } & \multicolumn{2}{|l|}{ 6. Date Comments Due: } \\
\hline \multicolumn{6}{|c|}{ 7. Review Criteria: Full } \\
\hline \multicolumn{4}{|c|}{ 8. Reviewer/Organization/Phone No.: Michael D. McKinnon, NDEP 486-2874 } & \multicolumn{2}{|l|}{ 9. Reviewer's Signature: } \\
\hline $\begin{array}{l}\text { 10. Comment } \\
\text { Number/ } \\
\text { Location }\end{array}$ & 11. Type* & 12. Comment & \multicolumn{2}{|l|}{ 13. Comment Response } & 14. Accept \\
\hline $\begin{array}{l}\text { 1) Page ES-1, } \\
\text { 3rd Para. }\end{array}$ & & $\begin{array}{l}\text { To be consistent with the rest of the document, add pesticides to the } \\
\text { list of contaminants of potential concern (COPCs). }\end{array}$ & \multicolumn{2}{|c|}{$\begin{array}{l}\text { The COPC lists throughout the document have been modi- } \\
\text { fied to include the following: } \\
{ }^{*} \text { Gamma emitters } \\
{ }^{*} \text { Total VOCs } \\
{ }^{*} \text { Total SVOCs } \\
{ }^{*} \text { RCRA metals } \\
{ }^{*} \text { TPH-diesel range organics } \\
{ }^{*} \text { Total pesticides } \\
{ }^{*} \text { Polychlorinated biphenyls (PCBs) } \\
\text { All soil samples collected from the test pits will be submitted } \\
\text { for laboratory analyses for the specified COPCs. Additional } \\
\text { samples may also be collected for waste management } \\
\text { purposes. }\end{array}$} & Yes \\
\hline $\begin{array}{l}\text { 2) Section 2.4, } \\
\text { Page 10, } \\
\text { 1st Para., } \\
\text { 6th Line }\end{array}$ & & "vitrified" vice "virtified". & \multicolumn{2}{|l|}{ Correction has been made. } & Yes \\
\hline
\end{tabular}




\section{NEVADA ENVIRONMENTAL RESTORATION PROJECT}

\section{DOCUMENT REVIEW SHEET}

\begin{tabular}{|c|c|c|c|c|}
\hline $\begin{array}{l}\text { 10. Comment } \\
\text { Number/ } \\
\text { Location }\end{array}$ & 11. Type* & 12. Comment & 13. Comment Response & 14. Accept \\
\hline $\begin{array}{l}\text { 3) Section } 4.2 \\
\text { Page } 17, \\
\text { 1st Para., } \\
\text { 2nd Line }\end{array}$ & & $\begin{array}{l}\text { "... Sampling activities... will be focused...at the northwest corner of } \\
\text { the decontamination pad..." This statement conflicts with Section } \\
3.0,1^{\text {st }} \text { bullet: "...Characterize the surface and shallow subsurface } \\
\text { soils near the northeast corner of the decontamination pad...", } \\
\text { Section } 2.5, \text { "...from the northeast corner of the decontamination } \\
\text { pad...", and Page ES-2, } 1^{\text {st }} \text { bullet, "...near the northeast corner of the } \\
\text { decontamination pad..." Ensure all sampling location references are } \\
\text { consistent. }\end{array}$ & $\begin{array}{l}\text { All references to the sampling locations have been checked } \\
\text { for consistency. } \\
\text { Section 4.2, Page 17, 1st Paragraph, } 1 \text { st sentence text } \\
\text { states: } \\
\text { Sampling associated with CAU } 252 \text { will be focused within } \\
\text { the sump area (west of the ETS-1 Decontamination Pad) } \\
\text { and in the soil near the northeast corner of the } \\
\text { decontamination pad. }\end{array}$ & Yes \\
\hline $\begin{array}{l}\text { 4) Page 18, } \\
\text { 1st Para. }\end{array}$ & & $\begin{array}{l}\text { For samples analyzed off-site for radionuclides, those which exceed } \\
\text { the FSLs will be selected; however, it is not apparent how these } \\
\text { samples (which should total 25\%) will be selected in the event the } \\
\text { FSLs are not exceeded. }\end{array}$ & $\begin{array}{l}\text { All soil samples collected from the test pits will be submitted } \\
\text { for laboratory analyses for the specified COPCs as follows: } \\
\text { *Gamma emitters } \\
\text { "Total VOCs } \\
\text { *Total SVOCs } \\
\text { "RCRA metals } \\
\text { *TPH-diesel range organics } \\
\text { *Total pesticides } \\
\text { "Polychlorinated biphenyls (PCBs) } \\
\text { Samples may also be collected for waste management } \\
\text { purposes. }\end{array}$ & Yes \\
\hline $\begin{array}{l}\text { 5) Section 5.0, } \\
\text { Page 20, } \\
\text { 2nd Para., } \\
\text { 2nd Line }\end{array}$ & & $\begin{array}{l}\text { "...The same is true for the contamination rinsate..." Change to } \\
\text { "decontamination" rinsate. }\end{array}$ & Correction has been made. & Yes \\
\hline $\begin{array}{l}\text { 6) Section } \\
\text { 5.3.4, Page } \\
\text { 24, Last Para. }\end{array}$ & & Change Mutual Consent Order to Mutual Consent Agreement. & Correction has been made. & Yes \\
\hline $\begin{array}{l}\text { 7) Page A-3, } \\
\text { 7th Line }\end{array}$ & & End this sentence after "Road K"; delete "for the ETS-1 facility". & Correction has been made. & Yes \\
\hline
\end{tabular}




\section{Distribution}

*Provide copy in distribution of Revision 0 and subsequent revisions if applicable. Copies of only the NDEP-approved document will be distributed to others.

Paul J. Liebendorfer

State of Nevada

Bureau of Federal Facilities

Division of Environmental Protection

333 W. Nye Lane, Room 138

Carson City, NV 89706-0851

Mike McKinnon

State of Nevada

Bureau of Federal Facilities

Division of Environmental Protection

555 E. Washington, Suite 4300

Las Vegas, NV 89101

Sabrina Lawrence

Environmental Restoration Division

DOE/Nevada Operations Office

P.O. Box 98518, M/S 505

Las Vegas, NV 89193-8518

Janet Appenzeller-Wing

Environmental Restoration Division

DOE/Nevada Operations Office

P.O. Box 98518, M/S 505

Las Vegas, NV 89193-8518

Sabine Curtis

Environmental Restoration Division

DOE/Nevada Operations Office

P.O. Box 98518, M/S 505

Las Vegas, NV 89193-8518

Steve Nacht

Bechtel Nevada

P.O. Box 98521, M/S NTS306

Las Vegas, NV 89193-8521
2 (Controlled)* $^{*}$

1 (Controlled)*

1 (Controlled)*

1 (Uncontrolled)*

1 (Uncontrolled)*

1 (Uncontrolled)* 
Shannon Parsons-DePry

Bechtel Nevada

P.O. Box 98521, M/S NTS306

Las Vegas, NV 89193-8521

Jeff Johnson

IT Corporation

P.O. Box 93838

Las Vegas, NV 89193

Juliana Herrington

SAIC

P.O. Box 93838

Las Vegas, NV 89193

IT Corporation Central Files

IT Corporation

P.O. Box 93838

Las Vegas, NV 89193

Technical Information Resource Center

DOE/Nevada Operations Office

IT Corporation

P.O. Box 93838

Las Vegas, NV 89193

U.S. Department of Energy

Office of Scientific and Technical Information

P.O. Box 62

Oak Ridge, TN 37831

Manager Southern Nevada FFACO

Public Reading Room

P.O. Box 98521, M/S NLV040

Las Vegas, NV 89193-8521
1 (Uncontrolled)*

1 (Uncontrolled)*

1 (Controlled)*

1 (Uncontrolled)*

1 (Uncontrolled)

1 (Uncontrolled, electronic copy)

1 (Controlled)

1 (Uncontrolled) 
Manager Northern Nevada FFACO

Public Reading Room

c/o Rosa Silver

IT Corporation

P.O. Box 93838

Las Vegas, NV 89193

FFACO Public Reading Rooms Coordinator

Rosa Silver

IT Corporation

P.O. Box 93838

Las Vegas, NV 89193
1 (Uncontrolled)

1 (Controlled) 